Historic, archived document

Do not assume content reflects current scientific knowledge, policies, or practices. 



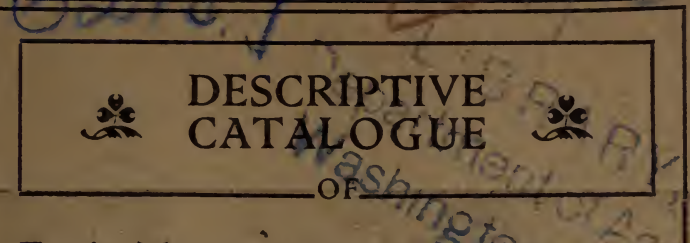

Fruit Trees, Vines, Smât Fruits, Ornamental Trees, Shrubs. Plants, Roses, Etc. Grown and for Sale by

\title{
Marshall Bros.
}

111

\author{
Proprietors of the
}
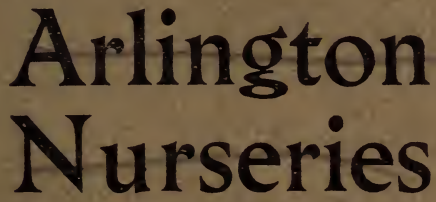

AND FRUIT FARM

\section{Arlington, Nebraska}

Long Distance Telephone No. 4

Arlington Telephone-Office No. G26.

Various Nursery Nos. $-26, \mathrm{H} 26, \mathrm{O} 26, \mathrm{~B} 4$ and Q26. References-Arlington State Bank; First National Bank, Arlington, and the Commercial Agencies 


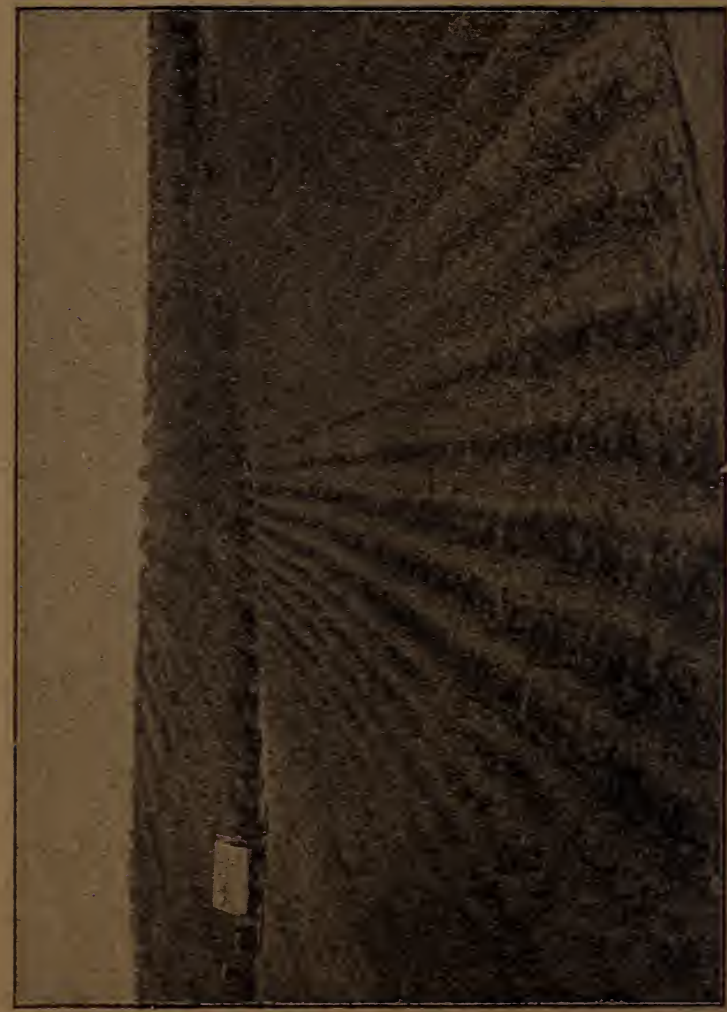




\section{What Some of Our Customers Say. * \&}

\section{CHARLES WOOSTER}

\section{Eagle Island Farm}

Silver Creek, Neb., July 21, 1904. Marshall Bros., Arlington, Neb.

Dear Sirs-Of the 800 peach trees and 100 apple trees I ordered of you last winter, all are living-have not lost a solitary one. I have cultivated them repeatedly, and they are doing nicely. In view of the fact that so many trees are lost ky farmers every year, I thought you would like to know of my success, which I attribute chiefly to the undoubted excellent condition and quality of the stock.

Very truly yours, CHARLES WOOSTER.

\section{THE UNIVERSITY OF NEBRASKA}

\section{Agricultural Experiment Station} $33 d$ and Orchard Streets

Lincoln, April 20, 1904.

Marshall Bros., Arlington, Neb.

Gentlemen-My trees received in good shape. I am well pleased with them. I enclose American Exp. money order in payment, as per bill rendered.

Very truly yours,

$$
\text { R. A. EMERSON. }
$$

\section{DEPARTMENT OF THE INTERIOR}

United States Land Office

O'Neill, Neb., April 19, 1904.

Marshall Bros., Arlington, Neb.

Gentlemen-The trees ordered from you arrived in first-class condition, for which accent thanks. Enclosed find draft in payment for same as per your advice.

From this and previous plantings I find 
your trees fine healthy stock, and your method of packing and shipping such that the trees are in good growing condition when they arrive. All my trees are doing fine and I have lost less than one per cent on the different varieties planted, which I certainly consider exceptional. Respectfully,

A. BAKER.

\section{BONESTEEL STATE BANK}

\section{(Incorporated)}

Bonesteel, S. D., April 16, 1904.

Marshall Bros., Arlington, Neb.

Gentlemen: Enclosed find draft in payment of my bill for trees, etc. I found everything satisfactory, and in the future when in need of any nursery stock I will rememker your firm

Yours very truly, F. L. CROSBY,

President Bonesteel State Bank. Hastings, Neb., May 5, 1904. Marshall Bros., Arlington, Neb.

Dear Sirs-Will you kindly send your catalogue to R. R. Murndorff, Clay Center, Neb. They want to get some strawberry plants. They saw our patch of berries and were very much taken up with them. We got our plants from you. I have the Bederwood and the Warfield.

Yours truly, W. A. BAKER.

140 East Sixth Street.

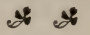

Lynch, Neb., April 18, 1904.

Marshall Bros., Arlington, Neb.

Gentlemen-The trees came in splendid condition. Thank you for accurate and good packing. Yours trulv.

GEORGE BRANDVIG. 


\section{SWIFT \& COMPANY}

\section{Union Stock Yards}

South Omaha, Neb., April 11, 1904. Marshall Bros., Arlington, Neb.

Gentlemen-Your shipment of fruit trees of recent date reached me in firstclass condition, and $I$ wish to thank you for the attention you have given to the selection of the trees.

They are a fine lot and in fine condition. Yours respectfully,

\section{A. HANSEN. \\ \& $\$$}

\section{LETTER.}

To Our Friends, Customers, and all Lovers of Fruit:

In presenting to your our Descriptive Catalogue we wish to say that we are situated in one of the oldest and best parts of the state, and are benefited by the results of from 30 to 35 years experience in orchard planting here, and with these results and knowledge gained by visiting hundreds of orchards in Nebraska and Western Iowa, and 17 years of hard study and constant experimenting to which we have given our whole time, we have selected from the list in this catalogue the varieties best suited to $\mathrm{Ne}$ braska and Western Iowa, which are marked with a star (*). Please notice this in making your selection. It is well to $r \in$ member that the harvest will depend on what you plant. The wise man has his harvest in view when he selects his stock. If you don't know what varieties you wish to plant, it is well to stick quite close to the star (*) sorts, as this mistake once made can never be satisfactorily rectified. 
We are continually discarding many varieties highly recommended for this country by people not living here. Our object is to grow such trees, vines, etc., as will do well in our Northern and Western climate. We are pleased to note that the dry seasons of 1893-94-95 and other dry seasons since have proved to our satisfaction that fruit trees under high, shallow cultivation will stand much more drouth than corn, small grain or grass. Our nurseries never were in better condition than now. Our young orchards are beginning to yield handsome returns, fruit finding ready sale in any market, East as well as West. We shall be pleased to hear from you at any time, and shall take pleasure in answering all inquiries to the best of our ability, whether you purchase or not. Send card for price list; come and see our stock. We will be glad to show you around at any time you can make it convenient to call. Thanking you for past favors, and hoping your patronage will grow, we are,

Very respectfully,

MARSHALL BROS.

Arlington, Nebraska.

\section{PREFACE.}

Our motto is to grow the best of all kinds of fruit trees, vines, plants, etc., that will succeed in this climate. We are conducting three experimental orchards in which we shall continue to experiment with all new promising varieties in our line, and hold fast to those that prove good. We shall hold no good things from our patrons, and from time to time will offer such as prove valuable. It is 
safe to assert that the Nursery business has kept abreast with all the other enterprises of the country. A host of new varieties of the various kinds of fruit have been brought to the front, some of which have been classed with those very worthy of cultivation, while many others have fallen back into the grave of oblivion, being classed as worthless and never again to be resurrected. The past few years have developed the fact that the fruit bus'ness and the growing of fruits for the market will be in the front rank of the great business enterprises of the West. This is evidenced by the large number of fruit trees that are being planted and the interest being manifested in the selection of varieties. We have not only to consult the wants of those who are planting large commercial orchards for the money to be derived therefrom, but our desire is also to reach the amateur and moderate planter, whose object is to grow a family orchard of the varieties best suited for dessert and home consumption, so that a succession of the best fruits from the earliest to the latest ripening may be obtained; and thus in preparing this catalogue the greatest pains have been taken to make the descriptions and seasons of ripening as accurate and intelligible a's possible.

Season of ripening as herein given refers to latitude 40 " to 44 " north.

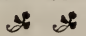

\section{ADVICE TO CORRESPONDENTS.}

When particular varieties are ordered state whether and to what extent other varieties may be substituted, in case the orders cannot be filled to the letter, as 
happens occasionally in all nurseries. When no instructions of this kind accompany the order, the best judgment will be exercised in filling the order so as tc render satisfaction to the purchaser. It is requested that explicit directions formarking and shipping stock accompany the order, but when such directions are not given it will be shipped the cheapest and most direct route by freight, unless it is deemed safest and best to ship by express, and in all cases the shipment will be at the risk of the purchaser, and if delay or loss occur in transit the forwarders alone must be held responsible.

Customers are requested to send notice at once of any error that may be committed in filling their order, so that it may be rectified and explained.

\section{$* *$}

\section{GUARANTEE OF GENUINENESS.}

While the greatest diligence and care to have all trees, etc., true to label will be exercised, mistakes may occur and in such cases upon proper proof the goods will be replaced free of charge, and it is mutually understood that our responsibility ceases at this.

NUMBER OF TREES AND PLANTS ON AN ACRE AT VARIOUS DISTANCES.

1 foot $x 1$ foot.......... 43,560

2 feet $x 1$ font............. 21, 780

2 feet $x \quad 2$ feet............ 10,890

3 feet $x 1$ foot............ 14,520

3 feet $x 2$ feet............ 7,260

3 feet $x 3$ feet........... 4,840

4 feet $x 1$ foot........... 10,890 


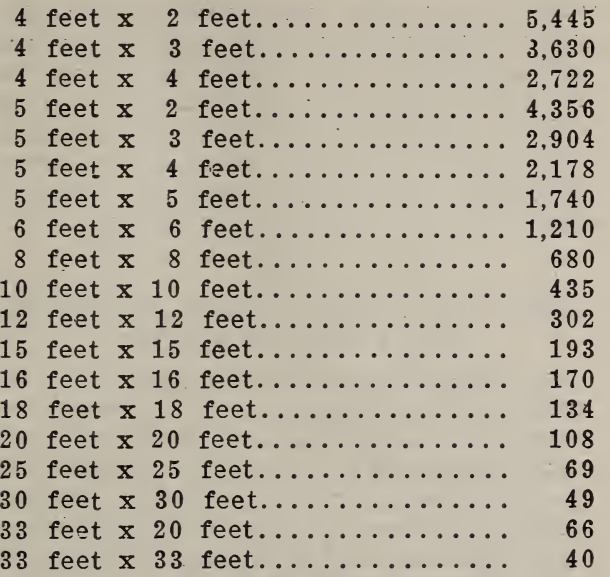
* *

\section{DIRECTIONS FOR TRANSPT,ANTTNG AND CARE OF NURSERY STOCK.}

\section{Introduction.}

While fruit growing requires as much intelligent care as corn or other grain, the nrofits are such as to encourage all who can give it proper attention, to plant freely. Among our customers we have noticed narties who derived more clear gain firm an acre of orchard than from ten acres of any other part of the farm. As to the most profitable varieties, we would refer those interested to the Star (*) sorts in this catalogie. It is not uncommon for small fruits to yield from $\$ 200$ to $\$ 300$ per acre.

Careless or ignorant nlanting of trees is very exnensive to the customer and damaging to the credit of the nurseryman, who after delivering to his custom- 
ers fine, healthy, well-grown trees, often has to kear the blame for the loss, though well knowing that it is oftentimes the fault or ignorance of the planter. The careful perusal of the following suggestions, based on wide observation, careful study and costly experience, will, if followed, give much better results.

\section{$* *$}

\section{CARE OF STOCK IVHEN RECEIVED FROM THE NURSERY.}

As soon as the trees and plants are recerted, the bundles should ke opened, removing all straw and packing and the roots thoroughly sprinkled, then heeled in very moist ground so that the mellow earth will come in contact with the roots and thoroughly protect them from the air, having earth tamped solid about them. Wet down thoroughly and cover wet soil with two or three inches of mellow earth. In planting take up only a few at a time, and never allow them to lay exposed to the air and sun.

\section{For Planting Fruit Trees, Etc.}

Have the ground thoroughly prepared by deep plowing, and drag fine; and in planting make the hole large enough to admit the roots in their natural position; set the tree solid four or five inches deeper than it was in the nursery. If the soil is not quite moist enough, tamp it to the roots same as about a post, then water so thoroughly as to wet the soil in the hole; finish filling the hole and leave two or three inches of the surface soil loose. In planting (apples especially) lean the tree slightly to the southwest, putting the largest and lowest limbs on 
that side, to prevent sun scald. Cut back from one-third to one-half of last year's growth; keen the soil perfectly mellow by cultivation; or, in other words, care for them as you do for your corn or potatoes. It is well to plant some cultivated crop in young orchards, not planting closer than six feet to trees. If this is impossible, mulch six inches deep and eight feet wide. Never manure ground Where you expect to plant a young orchard unless ground is too poor to raise corn; also use as weak mulching as can be obtained. The trees should be kept free from caterpillars and leaf rollers.

Would plant Cherry and Plum trees 16 or 18 feet apart, in rows running east and west, with rows 14 to 16 feet apart, planting no one variety in two adjoining rows. The object is to have the north and south winds of the spring to intermix the pollen, which is the secret of success, especially in plum growing.

Would plant Apples 25 to 30 feet apart. The higher elevations and northern and eastern slopes are the most desirable locations for commercial orchards, yet the family orchard should be near the house, and if this location should be a south slope, plant closer, say 20 to 25 feet. Allow the trees to limb low; shane the tree while small, with central body (no forks', and not over 4 or 5 limbs evenly and widely distributed outside. Never prune much, as the tree attains age, cutting off only the water sprouts and limbs that cross and rub, always encouraging the growth of the south side of the top. A wind break on the south and west will help much in growing a shapely tree. Bearing orchards that are sown in grass 
should be mowed two or three times each year, leaving grass lay to hold moisture and act as a mulch in winter. Some orchards are nearly ruined by having crops of hay taken from them during dry weather.

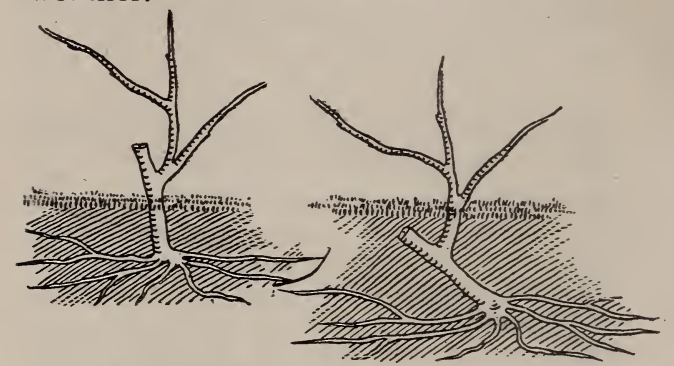

Too Shallow. Planted Just Right.

Grapes should be planted 18 inches deep, in holes large enough to admit roots without curling them around; press soil solid about roots, leaving two inches of surface soil loose. Be sure to plant four or five inches deeper than they were in the nursery, leaving only three or four buds above ground; plant six or eight feet apart. Keep ground clein by cultivation; if impossible to cultivate, mulch same as apples. Prune in November, before covering for winter. We regard covering profitable in most localities of the West. Use old hay or dirt in covering.

Raspberries and Blackberries should be planted in well pulverized soll, two or three inches deeper than they stood in the nurseries, and soil kept loose by thorough cultivation. Plant Racnberries two and a half feet apart in rows, having the rows five or six feet apart. Prune in spring, cutting out all old wood, and cut 
back new wood to three or four feet. Always keep your Raspberry patches clear of weeds by cultivation, and prune each spring, and it will pay you for your trouble. Plant Blackberries two feet and a half apart in rows, having rows six or seven feet apart. Prune in winter or

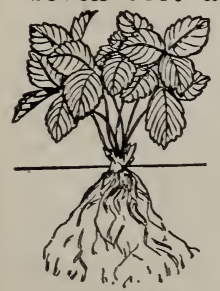

Just Right

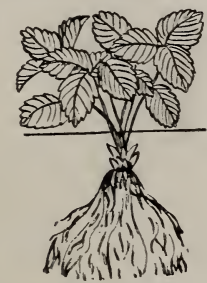

Too Deep

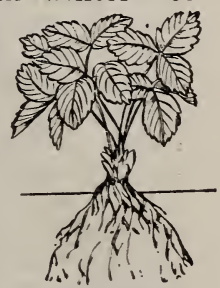

Too Shallow

spring; take out all old wood and cut back new wood to three or four feet.

Strawberry plants should be planted and cared for the same as cabbage or tomato nlants. Plant in rows three to three and a half feet apart and twelve to fifteen inches in the row. The cheapest way to grow them is to plant in long rows and tend with a corn plow, using shields. Never allow rows to spread to more than eight or ten inchos in width. Cover the plants late in the fall with one or two inches of prairie hay or stable litter (if free from weed seedi. This covering should be removed from the plants in early spring and left between the rows until fruit is picked; then it should be removed from the patch, the plants mowed close to the ground, then the rows cultivated as before.

Currants and Gooseberries should be planted four feet anart each way and mulched heavily. Soft coal ashes and cinders are good for mulching. They bear 
better when sheltered from south winds. Currants should be in the shade of fruit trees or other small trees at least half the day-say the afternoon. The north side of a picket or board fence is an ideal place for Currants and Gooseberries.

Evergreens should be planted extremely solid, but be sure that all vacancies under the pronged roots are well filled with soil first, then press or tramp the soil so solid that the tree cannot be easily pulled up, leaving two inches of the soil loose to prevent baking and to take in rainfall. Be careful never to expose the roots to the sun and air long enough to dry them. In watering it is better to dig a hole by the side of the tree one foot deep and water through the hole. This applies to the watering of all trees. Better to water two or three pailfuls at a time through the hole at the side of the tree once a week or ten days, as needed, than to pour water on the surface, which often does more harm than good, ky crusting the surface and attracting the roots uriward for moisture instead of downwryd. Mulch with old hay or chaff; throw a little soil over the mulching, and it will ke more effective and look better. Evergreens should be watered during a drouth in midsummer, or fall, as well as in the spring. The ground should be filled with water at the approfch of winter, and then mulched. They do not need the above care after the first year.

\section{MISCELIANEOUS.}

If weather is too dry for fresh planted trees to start, mulch and wet down with three or four pails of water per tree. 
A small mound of earth placed against each fruit tree in autumn will keep mice away during winter; but must be removed in the spring.

Guard against rabbits by wrapping trees. Four or five cornstalks stood around the tree and tied with two strings is the easiest preventive.

If roots are not damp with dirt sticking to them, dip them in mud stirred like mortar before planting.

Avoid pruning the south side of body or $\operatorname{limb}$, as the sun prevents the healing of the wound.

Never sow grass seed in an orchard till it has been planted a few years.

Clover is the only grass fit to grow in an orchard, as all others form too stiff a sod.

Never take a crop of hay out of your orchard.

Manure will never hurt a bearing orchard.

\section{HOW TO WINTER TREES RECEIVED IN THE FALL.}

Soon as trees and plants are received from the nursery the bundles should be opened and all straw and moss taken from them; then dip roots in thin mud; heel in one foot deep in moist ground, laying trees at such an angle as to have tops one foot above ground; tramp dirt solid about the roots. Leave them in this condition until late in fall, then cover the entire top with dirt, using nothing else. Forest trees, Grape vines and Berries should be buried-in pure dirt. Plant April 1st to 10 th.

Treatment of trees, etc., that have been 
frozen in the packages or received during frosty weather: Put them unopened in a cellar, or some other cool, protected place, free from frost, or cover them up heavily and completely with earth until they are entirely thawed out, when they can be unpacked and planted or placed in trenches until convenient to plant. Treated in this way they will not be injured by the freezing.

\section{$* *$}

SPRAYING FORMULAS.

Paris Green-Paris Green, one pound; water, 100 to 300 gallons. If this mixture is to be used upon fruit trees add one pound of quicklime, as repeated applications will injure most foliage unless the lime is usad. Paris Green and Bordeaux Mixture can be applied together with perfect safety. Use at the rate of four ounces of the arsenites to fifty gallons of the mixture. The action of neither is weakened and the Paris Green loses all caustic properties. For insects which chew.

Bordeaux Mixture - Dissolve six pounds of sulphate of copper in six gallons of water. In another vessel slack six pounds of fresh lime in six gallons of water; after the lime has cooled, turn slowly into the copper solution, add thirty-eight gallons of water, mix thoroughly and strain through a coarse gunny sack, when it is ready for use.

The above preparation is used for all kinds of fungus diseasea, such as mildew, mould, scab on apples, rot on granes, and for all forms of leaf blight. Application should be made with a sproy pump as soon as the disease appears, and repeated twice at intervals of ten days. For cod- 
ling moth add to the Bordeaux mixture one-quarter pound of Paris green. Apply as soon as the blossom : $:$ of and repeat after ten days.

Kerosene Emulsion-Dissolve one-half pound of hard soap in one gallon of hot water and heat to boiling; add one quart kerosene and stir violently for five minutes until the whole is thoroughly mixed together; add fourteen quarts of water and mix thoroughly, when it is ready for use. This mixture is used to destroy plant lice of all sorts, and that class of insects which suck the sap of plants through a beak.

Ammoniacal Solution of Copper Carbonate-Dissolve three ounces of carbonated copper in one quart of ammonia and add 25 gallons of water.

The above is used for various fungus diseases, principally black rot in grapes.

All of the solutions of conner corrode iron and tin, and should be mixed in wooden, earthen or brass vessels.

Copper Sulphate Solution-Copper sulphate, 1 pound; water, 15 gallons. Dissolve the copper sulphate in water, when it is ready for use. This should never be applied to foliage, but must be used before the buds break. For peaches and nectarines use 25 gallons of water. For fungus diseases.

Hellebore-Fresh white Hellebore, 1 ounce; water 3 gallons. Apply when thorougly mixed. This poison is not so energetic as the arsonites and may be used a short time $b$ ?fore the sprayed portions mature. For insects which chew.

Resin Compound-Sal sola (crystalized), 4 pounds; resin, 8 pounds; water, 
1 quart. Mix and boil until resin is all dissolved, and while hot add water enough to make 3 gallons and boil a few minutes. Let cool and then add water to make five gallons. This is the stock solution. When ready to use it, dilute the stock solution, using one gallon of it to about seven gallons of water. This is for plant lice either on outdoor plants or house plants. On the latter it may be washed off the leaves after it has killed the insects attacking them. Does not injure the most tender foliage, cucumbers, melons or peaches. Used and heartily recommended by the managers of the University State Farm at Lincoln, Neb.

If the above does not give satisfaction then try Kerosene Emulsion, given on page 15 of this catalog.

Tobacco Decoction-A spray for plant lice, etc. Steep the midveins or "stems" of tobacco leaves in an amount of water sufficient to cover them, and, when their strength is well drawn out, dilute the liquid until it has the color of fairly strong tea. Spray on the plants, taking care that the insects to be destroyed are reached by the decoction.

\section{ROSES AND OTHER ORNAMENTALS}

Their Pests and Remedies for Same.

The Rose Slug, (Seladria rosea.)-A light green insect akout an inch in length. There are apparently two kinds, one of which eats only the outer skin of the leaf on the under side, the other eats the leaf entire.

As a preventative use a solution of one pound of whale oil soap in eight gallons of water, as a spray. Applied daily for a week in the spring before the buds be- 
gin to develop, it will never fail to prevent the attacks of this insect. If this precaution has been omitted and the insects are seen on the leaves, white Hellebore dusted on the plants will be quickly effective.

Red Spider, (Acarus tellarius.)-So small as to be practically invisible to the naked eye. Works on the under side of the leaf, which has a sickly, dusty appearance and finally drops from the plant. Cannot thrive except in a dry hot atmosphere. Hard spraying with clear water several times da'ly, after picking and burning the leaves most affected will be found effective.

Mildew-A parasitical fungus common to vegetation that is exposed to sudden changes of temperature. Chilly nights in spring and fall cause it to appear on roses, etc. Sulphur applied in various forms is a certain specific. For a spray dissolve one ounce of potassium sulphurate in two gallons of water. This is very effective. Pulverized sulphur dusted over the affected foliage while the dew is on, is also good.

Kerosene Emulsion-Kerosene in its natural undiluted state is fatal to all insect and vegetable life, but properly prepared may be used safe'y and with much benefit.

Dissolve a bar of Ivory soap in one gallon of hot water, then add two gallons of kerosene and churn it vigorously until cool. If made right, it is then like cream, and will keep indefinitely. For general use, take 1 part of the mixture to 10 parts water and use as a spray. Will be found very valuable in getting rid of aphis, scale, and in fact a great many insects. 


\section{Fruit Department}

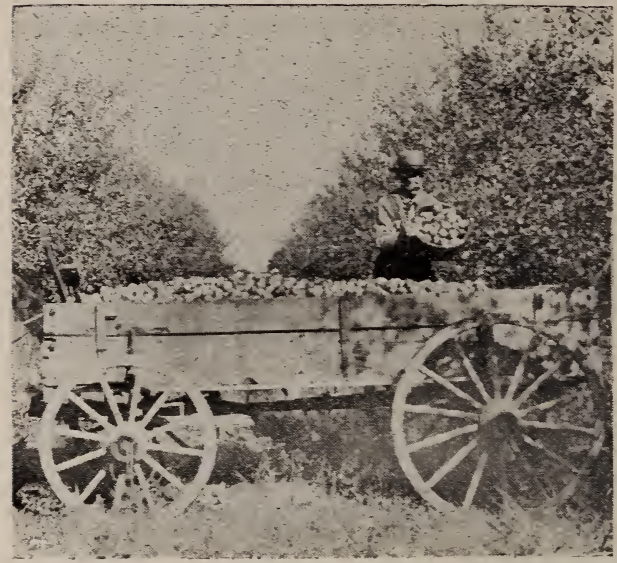

\section{The Apple}

The apple is the first fruit, both in importance and general culture. No fruit is more in demand, more universally liked or more generally used. The earlier varieties ripen about the last of June, and the later sorts can ke kept until that season. It is a fruit in perfection the entire year. Make a judicious selection of varieties, and a constant succession can be had the whole year.

Its uses are many and of inestimable value. It has been sa:d that "fruit is nature's own remedy"; it is certainly nature's own preventative. Many diseases are not known to free users of a fruit or vegetable diet. There is no farm crop 
which, on the average, will produce onefourth as much income per acre as will a good apple orchard.

We grow about fifteen varieties in large quantities, and advise beginners to not plant more than that many. We grow a limited supply of over 100 sorts, and therefore can supply anything in this book and many not listed. Those marked with a star (*) will give best satisfaction in northern Nebraska.

\section{SUMMER APPLES.}

American Summer Pearmain-Medium oblong; striped and dotted with red; tender, juicy and rich; good grower and moderate bearer. August.

Astrachan Red. - Large, roundish, nearly covered with deep crimson, overspread with deep bloom; juicy, rich and beautiful; a moderate bearer; tree upright, spreading; July.

Benoni.-Medium, red striped, best of its season; tree upright; good bearer; blights some; August.

Chenango Strawberry. - (Sherwood Favorite.) Fruit medium size, oblong, indistinctly ribbed; skin whitish, splashed and mottled with light and dark crimson; flesh white, tender, juicy, with a mild, sub-acid flavor. A pleasant fruit, esteemed for the table, and so handsome as to make it a quick selling market variety. Tree vigorous but blights some, is a good annual bearer. August and September.

Cole's Quince.-Large, yellow, ribbed, moderately hardy, productive. August and September. Specially good for cook-

The "Star" (*) Varieties are the Leaders. 
ing, where the quince flavor is liked by consumers.

Cooper's Early White.-Very large, roundish, pale yellow with faint blush; flesh white, crisp, sprightly; a Western apple; vigorous; not hardy in central $\mathrm{Ne}$ braska; first of August.

*Duchess of Oldenburg.-Fruit large, striped, beautiful, quite juicy, mild subacid, or almost tart; tree a good bearer, with upright head, requiring little or no pruning; very hardy. Indispensable north and west, good south, and a favorite east. One of the best for culinary use, being particularly well adapted for cooking and drying. July and August.

Early Harvest. - Medium to large, roundish, bright straw color; flesh white. tender, juicy, crisp, with rich sub-acid flavor; tree moderately vigorous and productive. First of July.

Early Pennock. - Tree moderately hardy; very productive; fruit large, roundish, conical ribbed, light yellow, splashed, mottled and shaded with light red; sub-acid, fairly good, core large. August and September.

Keswick Codlin.-Moderate size, tender, juicy, excellent for cooking; productive and early in bearing; July and August. Hardy.

Red June.-Medium size, flesh white, tender, juicy, sub-acid; an abundant bear er; last of June. Tree moderately hardy.

Sweet June.-An excellent early sweet apple; pale greenich yellow, medium size, round; fine for table and cooking, tender; 25 th of June to middle of July.

Sops of Wine.-Medium size, dark red; quality excellent; tree very hardy and productive. August. 
Tetofska.-(Russian.) The tree is an upright spreading grower, forming an open head; comes into bearing extremely early and bears every year; blights some; fruit medium size, nearly round, whitish yellow beautifully striped with red. Flesh white, juicy, pleasant, acid, aromatic; very slow in nursery. A dwarf tree. July.

*Yellow Transparent. - (Russian.)Large, pale, waxen yellow, oblate, beautiful, quality good, an upright grower, perfectly hardy; a good tree for $\mathrm{Ne}$ braska; July 15.

\section{AUTUMN APPLES.}

Alexander.- (Empire Russia.) Large, deep red or crimson; flesh yellowish streaked, tender, juicy, fine, productive, very hardy, shy kearer; October.

Fulton Strawberry.-Medium size, streaked, tender juicy, fine, productive, desirable; August and Sentember.

Bailey's Sweet.-Fruit large, round, mottled and striped with deep red; flesh yellow and tender, with a mild, rich flavor; slow; blights some; September.

Dyer.-Medium size regularly formed, pale greenish yellow, faint blush, dark speck on one side, flesh white, very tender, juicy, good. August and September. Tree moderately hardy and very productive.

Fall Stripe.-(Saxton.) An old variety which originated in Massachusetts or Connecticut. Tree vigorous, very productive, an early bearer. Juicy, tender, sub-acid, slightly aromatic, very good; medium to small size, oblate, covered 
with light and dark stripes; does well in Nebraska; September.

Fall Winesap.-Origin unknown; tree a free, clean grower, moderately spreading, somewhat drooping as the tree acquires age; fruit medium size; green with red blush; very good; September.

Fameuse.-(Snow Apple.) Medium size, roundish, oblate; whitish ground, striped with red; flesh white, juicy and pleasant; tree blights; October and November.

Flora Belle.-Fruit medium, oblate; yellowish, shaded, splashed and mottled with crimson. Flesh whitish, mild, sub-acid, good. September.

*Golden Swede.-Brought from Sweden about 1870 by Mr. Lindgren of Oakland, Neb. Tree upright grower, spreading, vigorous, hardy; an early and annual bearer; fruit large, roundish, dull yellow, sub-acid; quality the very best; very desirable for Nebraska; August.

Haas.-(Gros Prommior.) Medium to large, slightly flattened, shaded and striped with red, flesh some times stained; sub-acid, fair quality; tree vigorous and hardy, upright grower, with well formed head, bears early; September to November.

Longfield.-One of the best of the Russian varieties; an early and prolific bearer, rich, sprightly, sub-acid quality, medium size, yellow, with a decided blush; October.

Maiden's Blush.-Rather large, oblate, sometimes ribbed, with a fine, evenly shaded red cheek or blush on a clear, pale yellow ground; flesh white, tender, sprightly, with a pleasant sub-acid flavor, 
bears large crops, free. August and September.

Porter.-R - - ther large, regular, orlong, tapering to the eye, skin bright yellow, some imes a dull blush in the sun; flesh tender, rich, sub-acid flavor fine; productive; slow; Sep:ember.

Fulton.-Said to be a seedling of Rambo, which it resemkles both in appearance and quality, only it is larger; tree hardy and a good bearer; October.

Price's Sweet.-Large, greenish yellow, flat shaped apple, claimed by many to be superior to Tallman Sweet; tree hardy, productive; November.

Rambo.-Medium, yellowish, streaked with dull red and somewhat dotted, mild, tender and good; not productive; September to November.

*Ramsdell's Swcet.-This old variety is esteemed wherever grown for the large crops which it bears and as a showy sweet apple for market and profitable for stock feeding, as well as for cooking. Tree very vigorous and comes into bearing early; flesh very tender; mellow, unusually sweet and rich; October to December.

*Wealthy.-Fruit large, variegated red; tree a good grower; an early winter apple in northern localities; a native of Minnesota and one of their hardy sorts; fine-grained, full of lively, sub-acid juice; commences to bear young: September.

*Utter.-Medium to large, roundish, whitish red, very good quality, an excellent variety; one of our best fall apples: September to October. Perfectly hardy.

The "Star" (*) Varieties are the Leaders. 


\section{WINTER APPLES.}

Allen's Choice-Origin Pennsylvania. Fruit below medium size, oblate, sides unequal, yellow, mo tly shaded, and striped with red. Flesh white, stained with red, coarse, crisp, juicy, aromatic "Good," January. Tree hardy in Nebraska.

Baldwin.-Large, roundish, deep bright red; juicy, crisp, sub-acid; good flavor; tree vigorous, upright; season November to December. Rather shy bearer and only moderately hardy in Nebraska.

*Ben Davis.-Large, smooth, often polished, nearly covered with red; subacid; one of the most profitable market fruits. Tree remarkably healthy and vigorous, productive, and bears early. December to February.

Black Twig.-A seedling of the Wine Sap, large, dark red, handsome, quality good; tree hardy. December to March.

Dominie. - (Well's English Red Streak.) Medium to large, skin greenish yellow; sometimes striped lightly with red; flesh very tender and pleasant; Blights in Nebraska. December.

English Golden Russet.-Fruit medium size, very rezular, slightly conical; pale greenish yellow, about two-thirds white, firm and crisp, with pleasant slightly sub-acid flavor; not profitable; November to January.

*Gano.-Supposed to be a cross between Ben Davis and Jonathan; bright red, no stripes, polished beautifully, oblong, tapering, surface smooth, sub-acid, good. One of the best for Nebraska; grayish red, flesh firm, mild, sub-acid; hardy, upright; tree resembles the Ben 


\section{Price List}

\section{Spring 1905}

$-\mathbf{O F}-$

\section{The Arlington Nurseries ARLINGTON, NEB. 300 Acres in the Business.}

Goods Laid Down at any Point in Nebraska or Western Iowa.

We Pay Freight on all Orders Amounting to $\$ 3.00$ or More.

WE GUARANTEE SATISFACTION!

\section{Read Carefully Before Ordering}

Your Name, Postoffice ard State should be distinctly written; also your freigh 5 and express office.

To strangers who have not already arranged matters by giving sati-factory references, we will ship goods C. O. D. if 10 per cent. or mcre of amount of order $h$ is been acranced before shipment.

when to Order. Order early and we will endeavor to ship your order on any day that you notify us to ship. We commet ce to fill orders as soon a the soil is in proper condition to plant. Earliest orders filled first.

Packing. We use the utmost care in facking, using plenty of moss to insure safe arıival. Everything is properly labeled, ar d further, if a mistake should occur. upon proper proof, the goods will be replaced free of charge.

We furnish 6 at dozen rat ss, 50 at 100 rates, an 1500 at 1 . 00 rates.

Customers are requested to notify us at $\mathrm{rn}$ e if anv enror rccurs in tilling orders. Our aim is to please each and every customer.

We guarantee all of our stock to be free from infectious dis' ases-heal'hy, vigorous and well formed trees. We send out nothing but first-class stock.

We dig our trees. shrubs, etc., with a large tr e digger. Yi u get all the roots

Anvihing not listed that is found in our Deseriptive Catalogue wili be priced on application.

IR enit Money b. Drati, P. O. or Express Money order or by Cash in Registered hetter. 


\section{PRICE LIST \\ For the Spring of 1905}

\section{FRUIT TREES}

Each, Pr.Dz. Pr. 100

\begin{tabular}{|c|c|c|c|}
\hline pple, & 2 to $3 \mathrm{ft} .1$ year. & 1.20 & $\$ 10.00$ \\
\hline “6 & 3 to $4 \mathrm{ft} .1$ and 2 years $12 \frac{1}{2}$ & 1.50 & 12.00 \\
\hline 66 & 4 to $5 \mathrm{ft} .2$ and 3 years 15 & 1.80 & 15.00 \\
\hline ، & 5 to $6 \mathrm{ft}$. extra fine....20 & 2.40 & 20.00 \\
\hline 6. & 6 to $7 \mathrm{ft}$. selected. & 3.00 & 25. \\
\hline
\end{tabular}

Windsor Chief-The highest award was won at the Paris Exposition on apples that were picked from the parent tree, or tree from which material for propagating our present stock of this fine variety was obtained.

Windsor Chief, 5 to $6 \mathrm{ft} \ldots \ldots \ldots \ldots . . .50$

$$
\text { . } \quad 4 \text { to } 5 \mathrm{ft} \text {..............40 }
$$

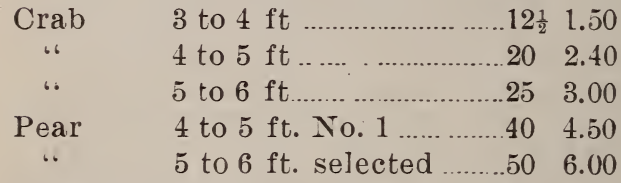

Cherry 3 to $4 \mathrm{ft} .1$ vear.............40 4.50

" 4 to $5 \mathrm{ft}$. extra fine......50 $\quad 6.00$

" $\quad 5$ to $6 \mathrm{ft}$. selected ..........60 $\quad 7.00$

، $\quad 5 \frac{1}{2}$ to $7 \mathrm{ft}$. extra large $\ldots 75 \quad 8.00$

Plum 3 to $4 \mathrm{ft}$. 1 year.............30 3.50

" 4 to $5 \mathrm{ft}$. extra fine .......40 4.80

"، 5 to $6 \mathrm{ft}$. selected ........50 $\quad 6.00$

“6 6 to $7 \mathrm{ft}$. extra larg€...60 $\quad 7.00$

Larsen Plum 5 to $6 \mathrm{ft}$.

" " 1 to $5 \mathrm{ft}$.

Apricot 3 to $4 \mathrm{ft}$. $30 \quad 3.50$ 
Fruit Trees ContInued.

Auricut, 4 to $5 \mathrm{ft}$

Each. Pr.Dz, 'r.100

66

$5 \mathrm{tn} 6 \mathrm{ft}$

$40 \quad 4.50$

Peach

3 to 4 ft

$.50 \quad 6.00$

،

4 to $5 \mathrm{ft}$

202.25

66

5 to $6 \mathrm{ft}$.

$25 \quad 3.110$

$35 \quad 4.00$

In all the ahove mentioned fruit trees, the 5 to $6 \mathrm{ft}$. extra fine and 4 to $5 \mathrm{ft}$. 2 and 3 year grades are most generally planted.

\section{G RAPES.}

Eıcb.Pr.Dz. Pr.100

Concord, 1 yr, No. 1, select

$75 \quad 4.00$

، $2 \mathrm{yr}$, No. 1, fine ............10 1.00 600

“ 2 and $3 \mathrm{yr}$, extra fine...15 $1.50 \quad 8.00$

Champion, 2 yr,

$20 \quad 2.00 \quad 10.00$

Clintou, 2 yr,

$\begin{array}{lll}20 & 2.00 \quad 100()\end{array}$

Herbert, 2 , r ,

$\begin{array}{lll}40 \quad 4.00 & 25.00\end{array}$

Ives, 2 yr,

$\begin{array}{lll}15 & 1.50 & 10.00\end{array}$

Moore's Earl:, 1 yr, No. 1

$\begin{array}{lll}20 & 2.00 & 10.00\end{array}$

“ $2 \mathrm{gr}$. No 1

Worden, 1 yr, No. 1

$\begin{array}{lll}25 & 2.75 & 12.50\end{array}$

2 vr, No. $1 .$.

151.50

8.00

$\begin{array}{lll}20 & 2.50 & 12.00\end{array}$

Camphell's Early, 2 yr,

$\begin{array}{lll}40 & 4.00 \quad 25.00\end{array}$

Mc Pike, 2 yr,

$\begin{array}{llll}50 & 5.00 & 3500\end{array}$

Agawam, $2 \mathrm{yr}$,

$\begin{array}{lll}20 & 2.00 & 10.00\end{array}$

Brighton, 2 yr,

$\begin{array}{lll}25 & 2.75 & 18.00\end{array}$

Delaware, $25 \mathrm{r}$,

$\begin{array}{lll}25 & 2.75 & 18.00\end{array}$

Wyoming Red, 2 yr.

$20 \quad 2.00$

14.00

Elvira, 2 yr.

$\begin{array}{lll}20 & 2.00 & 10.00\end{array}$

Empire State, 2 yr,

$\begin{array}{lll}30 & 3.00 & 15.00\end{array}$

Goethe (Rogers No. 1) 2 yr..

$\begin{array}{lll}30 & 3.00 \\ & & \end{array}$

20.00

Mnore's Diamond, 2 yr,

$\begin{array}{llll}25 & 250 & 12.50\end{array}$

Pocklington, $1 \mathrm{yr}$, No 1

$\begin{array}{lll}20 & 2.00 & 10.00\end{array}$

$2 s \mathrm{r}$, No. 1 .

$\begin{array}{lll}25 & 2.75 & 1250\end{array}$ 


\section{MULBERRY.}

Each. Pr.Dz. Pr. 100

Russian Mulberry-

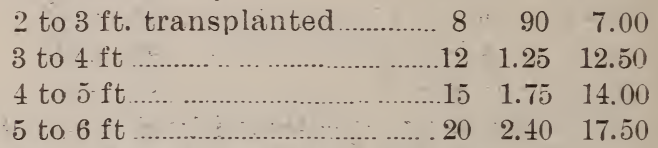

Downing Mulberry-

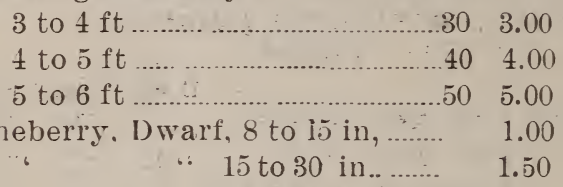

\section{NUT TREES. \\ Juneberry. Dwarf, 8 to 15 in, \\ $\therefore \quad 15$ to $30 \mathrm{in}$.}

Walnut, black, 3 tj $4 \mathrm{ft}$

Each. Pr.Dz, Pr.100

$$
\begin{aligned}
& \text { " } \quad \text { " } 4 \text { to } 5 \mathrm{ft} \\
& \text { " } \quad \text { " } 5 \text { to } 6 \mathrm{ft} \\
& 30-3.00 \quad 22.60 \\
& \begin{array}{ll}
75 & 8.00
\end{array}
\end{aligned}
$$
$20 \quad 2.00 \quad 1.5 .00$

Chestnut, Amer. Sweet, 4 to $5 \mathrm{ft} 50 \quad 6.00$

$$
\text { " } \quad \text { " } \quad 5 \text { to } 6 \mathrm{ft} 60 \quad 7.00
$$

Butternut, 4 to $5 \mathrm{ft}$ $50 \quad 6.00$

$$
\therefore \quad 5 \text { tó } 6 \mathrm{ft} \text {. }
$$

\section{BLACKBERRIES.}

Snyder, select roots...

$$
\text { .. as they run in row. }
$$

Stones Hardr, good plants Taylor 


\section{RASPBERRIES.}

BLACK.

Gregg, Kansas and Nemaha Older, Paimer and 'I'yler.

RED AND YELLOW.

Cuthbert and Turner (Red)

Cardinal, a cross between red and black, fine quality, new, very promising

Golden Queen (Yellow)

\section{STRAWBERRIES.}

Bederwood (S)

Pr.Dz. Pr. 100

Capt. Jack (S)

Crescent (P)

Gardner (S)

Marshall (S)

Parker Earle (S)

Robilison (S)

Sample $(P)$

Senator Dunlap (S)

The two last named varieties (Sample and Senator Dunlap) fertilize well together. Both are very prolific, of splendid quality. The two best new varieties known

Warfield (P), the best of all when planted with Bederwood Splendid (S)
$30 \quad 2.00$

$20-1.00$

Pr.Dz. Pr. 100

$75 \quad 4.00$

1.00500

$50 \quad 3.00$

$1.50 \quad 10.00$

$75 \quad 4.00$

20100

$30 \quad 2.00$

30 $\quad 2.00$

$30 \quad 2.00$

$30 \quad 2.00$

$40 \quad 2.50$

$40 \quad 2.50$ 


\section{CURRANTS.}

No. 2 plants, 1 and 2 years ............ 1.00

No. 1 plants, 2 years, Select ........ $\quad 1.50$

Fay's Prolific and Red Cross 1 yr. $\quad 1.50$

$$
\text { ". } 2 \mathrm{yr} . \quad 2.00
$$

\section{GOOSEBERRIES.}

Pearl, 1 year............................... 2.00

“ 2 year ............................... 2.50

Houghton, 1 year........................... 1.25

.. 2 year............................ 1.50

Smith's Improved, 1 year.............. 1.50

$$
\text { " " } 2 \text { year........... } 2.00
$$

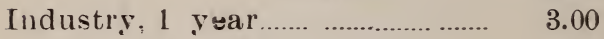

4.00

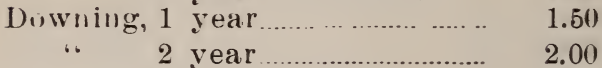

Champion

2.00

\section{GARDEN ROOTS.}

Asparagus, all varieties

$40 \quad 2.00$

Rhubarb (Pieplant) all varieties $\quad 1.00 \quad 800$ ORNAMENTALS.

DECINUOUS TREES.

Each Pr Dz. Pr. ${ }^{\prime} 00$

\begin{tabular}{|c|c|c|c|}
\hline $\mathrm{ft}$. & 6 & 50 & 4.00 \\
\hline 3 to $4 \mathrm{ft}$.. & 8 & 75 & 6.00 \\
\hline 4 to $5 \mathrm{ft}$ & 12 & 1.30 & 10.00 \\
\hline to $6 \mathrm{ft}$ & 18 & 2.00 & 15.00 \\
\hline ft..... & 30 & 3.25 & 25.00 \\
\hline $\begin{array}{l}10 \mathrm{ft} \\
12 \mathrm{ft}\end{array}$ & $\begin{array}{l}60 \\
.75\end{array}$ & $\begin{array}{l}6.00 \\
9.00\end{array}$ & 45.00 \\
\hline
\end{tabular}

Ash, Box Elder,Elm,S. Maple,

Ash, Mountain, all varieties.

4 to $5 \mathrm{ft}$.

5 to $6 \mathrm{ft}$. $50 \quad 6.00$ 
Deciduous Trees Continued.

Each. Pr.Dz. Pr.100

:iich, White American, 4 to $5 \mathrm{ft} .40 \quad 4.50$

$\begin{array}{llrrr}\text { ، } & \text { ، } & \text { " } & 5 \text { to } 6 \mathrm{ft} .50 & 5.50 \\ \text { " } & \text { ". } & \text { European, } 4 \text { to } 5 \mathrm{ft} .40 & 4.50 \\ & \text { "6 } & 5 \text { to } 6 \mathrm{ft} .50 & 5.50\end{array}$

Chestnut, horse, E'pean. 5 to $6 \mathrm{ft} .60 \quad 6.00$ Catalpa Speciosa,

5 to $6 \mathrm{ft} .30 \quad 3.00$

،

.6

Cherry, Wild, Black,

،

،

"6

Linden

$\therefore$

Locust, Black,

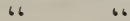

\begin{abstract}
6 to $8 \mathrm{ft} .40 \quad 4.00$
8 to $10 \mathrm{ft} .75 \quad 8.00$
\end{abstract}

4 to $5 \mathrm{ft} .40 \cdot 4.00$

5 to $6 \mathrm{ft} .50 \quad 500$

5 to $6 \mathrm{ft} .40 \quad 4.50$

6 to $7 \mathrm{ft} .50 \quad 600$

4 to $5 \mathrm{ft} .25 \quad 2.50 \quad 20.00$

5 to $6 \mathrm{ft} .30 \quad 3.00 \quad 25.00$

Masle, hard or Norway, 4 to $5 \mathrm{ft} .40 \quad 4.50$

$\begin{array}{llllll}\text { " } & \text { " } & \text { " } & \text { ". } & 5 \text { to } 6 \mathrm{ft} .50 & 5.50 \\ & & & & 6 \text { to } 8 \mathrm{ft} .60 & 700\end{array}$

Olive, Russian,

2 to $3 \mathrm{ft} .15 \quad 1.75$

3 to $4 \mathrm{ft} .25 \quad 2.75$

4 to $5 \mathrm{ft} .35 \quad 4.00$

Oak, Pin,

4 to $5 \mathrm{ft} 75 \quad 8.00$

، 6

Oak, Chestnut,

5 to $6 \mathrm{ft} .10010 .00$

4 to $5 \mathrm{ft} .75 \quad 8.00$

5 to $6 \mathrm{ft} .1 .0010 .00$

Poplar, Carolina,

5 t.) 6 ft. $15 \quad 1.50$

10.00

6 to $8 \mathrm{ft} .252 .50$

15.00

8 to $10 \mathrm{ft} .40 \quad 4.50 \quad 35.00$

10 to $12 \mathrm{ft} .506 .00$

، Silver leaved, 4 to $5 \mathrm{ft} .30 \quad 300$

$\begin{array}{llll}\text { * } \quad \text { " } & 5 \text { to } 6 \mathrm{ft} .40 & 4.00\end{array}$

" Lombardy 6 to $8 \mathrm{ft} .30 \quad 3.00$ 
Deciduous Trees Continued Sycamore,

6
6
66
66
66

Tulip Tree.

Each. Pr.Dz. Pr.100

Ginko, maiden hair tree, 4 to $5 \mathrm{ft} .758 .00$

$$
66
$$

$$
\because 6 \quad \text { 6 } \quad \text { 6 j to } 6 \mathrm{ftr} 1.0010 .00
$$

\section{WEEPING TREES.}

Each

Birch, Cut Leared Weeping 5 to 6 feet.... 1.75 Elm, Camperdown Weeping, 2 gear heads, 200 Mulberry, Tea's Weeping, 2 rear heads ....2 00 Ash, Weeping Mountain, 2 year heads...... 2.00 Willow, Wisconsin Wepring, 5 to 6 feet..... 50 Willow, Kilmarıock,

Willow, Thurlow, 5 to $6 \mathrm{ft}$. , extra fine ...... 50

" ، $\quad 4$ to j $\mathrm{ft}$.. extra fine...... 40

"6 New American, Weeping ..............1.00 Maple, Weir's Cut Leaf, 5 to $6 \mathrm{ft}$

" ، " " 6 to $7 \mathrm{ft} \ldots \ldots \ldots \ldots \ldots \ldots \ldots$

\section{SHRUBS.}

Each. Pr.Dz. Pr.100

Almond, Flowering, white or pink 35

$\begin{array}{ccccc}\text { Berbery. Common.................... } 20 & 2.00 & 12.00 \\ \text {. } & \text { Purple Leaved } & 20 . .20 & 2.00 & 12.00\end{array}$

Calycauthus .50 Honersuckle, Tree .................. Hydraugea No. 1 
Shrubs Continued.

Each,

Lilac, Persian .50

" Common Purple...............25

" White................................50

Snowball, 2 to $3 \mathrm{ft}$., extra strong..50

1 to $2 \mathrm{ft}$, No. $1 \ldots \ldots \ldots . . . . .40$

Spirea Anthony Waterer.............. 75

“ Tan Houtii............................50

Syringa

.35

Tamerix Amurensis (Russian) 4

to ó feet.

35

\section{VINES AND CEEPES.}

Clematis Jackmanni No, 1....................... 100

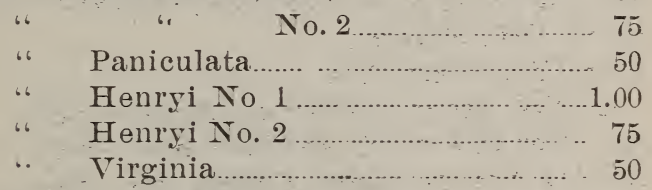

The Clematis Henryi is the finest white Clematis grown; very bardy and rapid grower, often covering the entire side of an ordinary building in a single season. Honessuckle, all varieties. 35 Ampelopsis Quinquefolia......................... 35

Nisteria …............................................. 35

\section{ROSES}

Each

All Roses, in catalogue, two yearsgrown in open ground, very fine, large plants $\left.5^{\prime}\right)$ Two year No. 2 or I year. 
ERRATA-

\section{BULBS}

Paeonia, assorted colors. No. 1

Dahlias,

Yucea

\section{EVERGREENS.}

Per Foot

in $\mathrm{Height}$

Austrian, or Black Pine. 20

Scotch Pine 20

White Pine

Norway Spruce

White Spruce 25

Arbor Vitae 20

Balsm Fir

Juniper, Swedish and Savin

Colorado Blue Spruce (Picea Pungens) ....1.00

Black Hills Spruce.

Dwarf Mountain Pine

All the above named evergreens that are 1 foot and over in size have been transplanted two or three times; are fine, stocky trees and can be supplied in all sizes, from 6 inches to 3 or 4 feet. All are sold for so much per foot as above quoted. For large quantities we send list of special prices.

FOREST TREE SEEDLINGS.

Ash,

8 to 12 inches

Pr 100 Pr. 1000

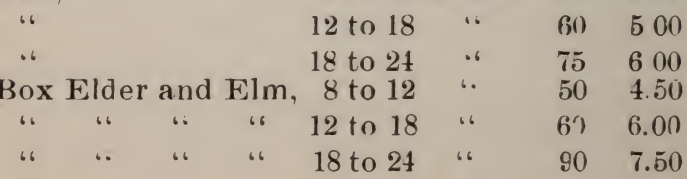


Forest Tre€ Seedlings Continued.

Cottenwood

6
6
6

Locust, Black.

.6

Maple, Soft,

$\begin{array}{ll}6 & 6 \\ 6 & 66\end{array}$

Mulberry, Russian,

66 66

Osage Hedge, Walnut, Black,

\author{
6
}

6 to 12 ،.

Pr. 100 Pr. 1000

12 to 18 '.

18 to 24 ،

30

2.50

2 to 3 feet,

3.00

$50 \quad 4.00$

12 to 18 inches, $80 \quad 7.00$ 18 to $24 \quad$ 66 $\quad 90 \quad 8.00$ 6 to 12 "“ 35 12 to 18 "6 18 to 24 6 60 ค. $75 \quad 6.00$ 8 to $12 \quad$ "6 $\quad 50 \quad 3.00$ 12 to 18 6. $\quad 60 \quad 5.00$

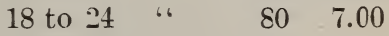
3.00 $\begin{array}{rrrr}8 \text { to } 15 & \text { 6 } & 1.25 & 12.00 \\ 15 \text { to } 2 t & \text { ، } & 1.50 & 15.00\end{array}$

\section{The Arlington Nurseries}

\section{And Fruit Farm}

Were awarded gold medal on Fruits at the Trans-Mississippi Exposition at Omaha in 1898; also a number of first and second premiums at the Paris Exposition in 1900: and the highest award on Apples at the Pan-American Exposition at Buffalo in 1901.

12,000 Quarts of Raspberries,

20,000 Quarts of Blackberries,

5,000 Baskets of Grapes,

Are not uncommon yields of the vineyards and small fruit

plantations during a single season.

Also, in connection with the business are orchards of

4000 Bearing Apple Trees,

1.000 Bearing Cherry Trees, 500 Bearing Plum Trees, 500 Bearing Peach Trees. 


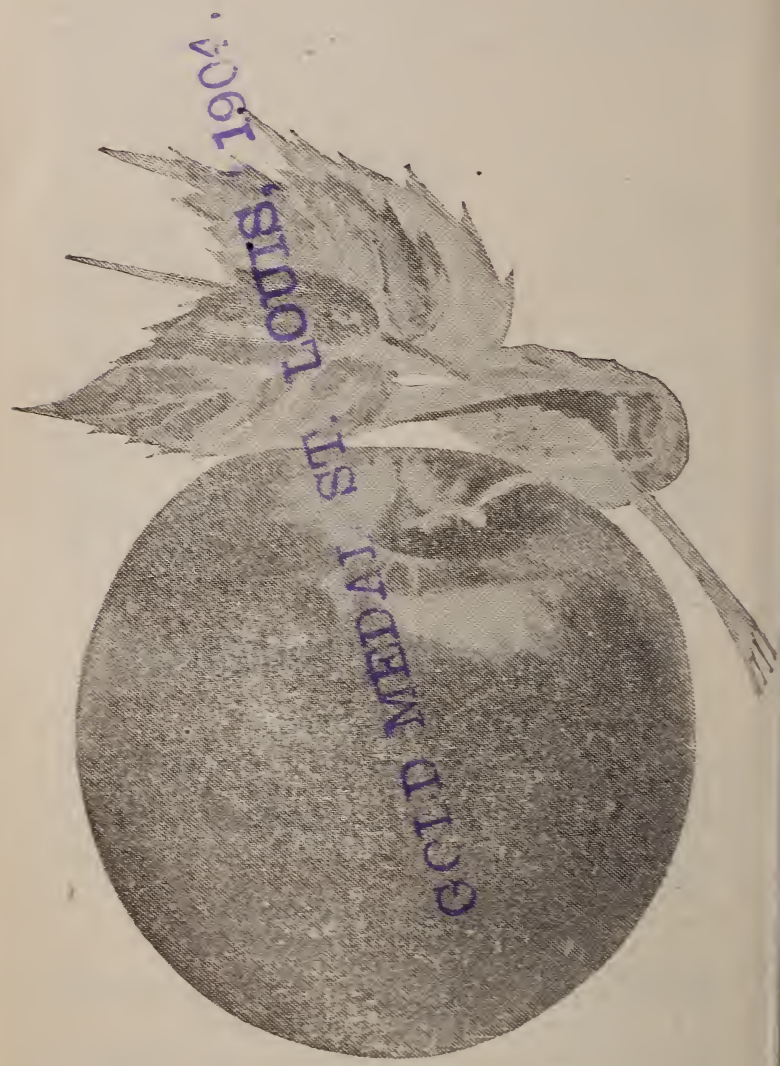


Davis. This is the coming market apple, as its heavy annual crops of large, red, showy apples will render it very profitable. It should le in every orchard.

G. G. Pippin.-(Grimes' Golden)-An apple of the highest quality, equal to the Newton, medium to large size; yellow, productive. November and December.

Iowa Blush.-Medium in size, roundish, conical, whitish, with red cheek; quality fine, tart; tree vigorous and hardy on the prairies. November to January. A good tree for Nebraska.

*Isham Sweet.-Fruit large, oblong, conical, greenish yellow; striped with dull red. Beautiful, showy, good; tree hardy, spreading. November to January.

*Janet.-(Never Fail.) Medium; mixed and striped crimson on yellow and green; flavor sub-acid, vinous and refreshing. Popular as a market fruit on account of its good quality and keeping qualities and abundant yields. The blossoms appear later than any other sorts, and thus they sometimes escape spring frosts. February to April.

Jonathan. - Medium; red, beautiful, best quality; tree slender; early and abundant bearer; moderately hardy. November to February.

Kaump.-Medium, yellow, good quality; early and constant bearer. Tree vigorous; very desirable at the north.

Lawver.-Origin Platte County, Missouri, large, dark, kright red, roundish, very showy, tree hardy; not productive; a late keeper. December to May.

Lansingburg.-Seedling of Little Romanite. Tree upright, spreading and productive, fruit medium, roundish, oblate, yellow, largely overspread with 
good; valuable mainly for its long keeping qualities; vigorous. February to June.

Little Romanite--(Gilpin Carthouse.) Tree productive; fruit below medium size, roundish, oklong, skin very smooth and handsome, streaked with long, deep red and yellow; flesh yellow, firm, rich, becoming tender in spring; good; vigorous. February to June.

Mann.-An upright grower, forming a round head, fruit medium to large, skin deep yellow when fully ripe, with sometimes a shade of brownish red where exposed, pleasant, sub-acid. Not productive. March and Anril.

McAfee's Red.-(McAfee's None-such.) Originated at McAfee's old Fort in Kentucky. Good grower; very productive, fruit large, shaded and striped with crimson, and covered with a thin bloom. Flesh whitish, solid, crisp, sub-acid, good to very good. Decemrer to March.

Milam.-A small red apple of excelleit quality; tree moderately hardy. Very productive. December.

Minkler.-Fruit medium, roundish oblate, slightly conical; pale greenish yellow, striped and splashed with two shades of red; flesh ye'lowish, compact, moderately juicy; milf, pleasant, subacid. Tree irregular grower, very spreading. A rather shy bearer and only moderately hardy in Nebraska. January to April.

Missouri Pippin.-Medium, oblong, bright red, with numerous gray dots, very handsome and a fair quality, an early and abundant bearer, and very profitable orchard fruit; vigorous. December to March. 
Northern Spy.-Fruit large, striped and shaded with light and dark purplish crimson and covered with a thin white bloom: tender, very juicy, a pleasant sub-acid. November and December. Shy bearer.

*Northwest Greening.-Tree of Wisconsin origin; vigorous grower and considered very hardy in that section, fruit large, of greenish yellow color, and remarkable as a keeper, fruit of 1884 and 1885 having been exhibited side by side.

Perry Russet.-Above medium, yellowi h green, partly covered with russet, quality good, tree hardy, very poor bearer.

Pewaukee.-Fruit very large, green, striped and splash॰d with red. Fruit drops from tree, not hardy.

Roman Stem.-Fruit medium, whitish yellow snlashed with russet; flesh tender, juicy; rich musky flavor, fine dessert apple; moderately hardy. Novembor and December.

Seek no Further.- - (Westfield.) Medium tó large; slightly russeted with dull red stripes, tender, rich, spicy and fine; good kearer, moderately hardy. October to January.

Sheriff.-(American 'Beauty.) Above medium, roundish, oblong, flattened at the ends, regular, nearly covered with light and dark red stripes and splashed with obscure dots; early bearer, productive, moderately hardy. November to February.

* Salome.-Above medium in size, partly shaded and striped with dull red, tender, mild, slightly aromatic; very good. December to March. Its hardiness, long 
keeping, good quality, uniform size, will no doubt make it valuable for the west and northwest. Perfectly hardy.

Tallman Sweet.-Medium, pale yellow, firm, rich and very sweet; October to December.

White Winter Pearmain.-Medium, oblong, skin yellowish, sometimes

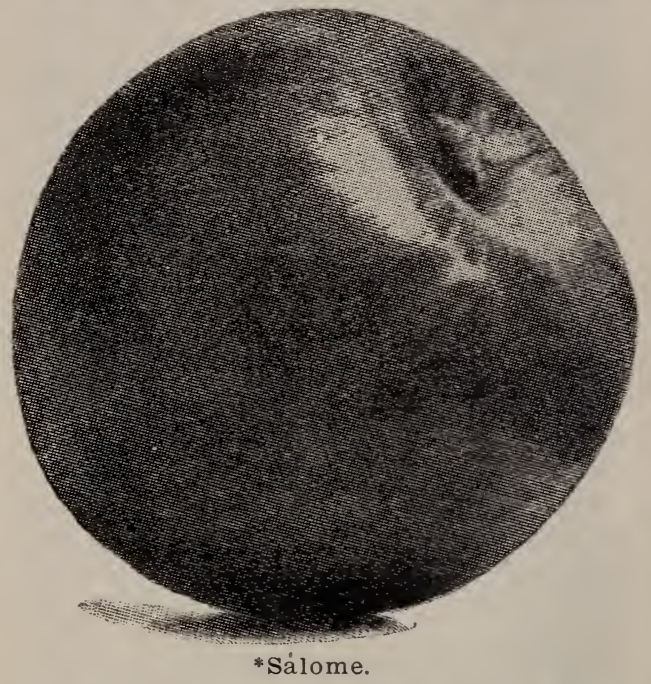

bronzed, flesh yellow; with a pleasant sub-acid flavor; tree productive. January to April.

Willow Twig.-Large, roundish, greenish yellow, striped, early bearer and considered valuable in the south, profitable as a late keeper. January to May. Blights in Nebraska.

* Wine Sap.-Medium dark red, subacid, excellent, abundant bearer, a favor- 
ite market variety in the west; vigorous and hardy. November to April. A good one for Nebraska.

*Windsor.-(Windsor Chief.) Medium to large; greenish yellow, suffused with red splashes, becoming quite red when ripe; gray dots, flesh pale yellow, sometime streaked with red; fine grained, juicy, sub-acid, good to very good. Tree an upright, moderate grower, becoming

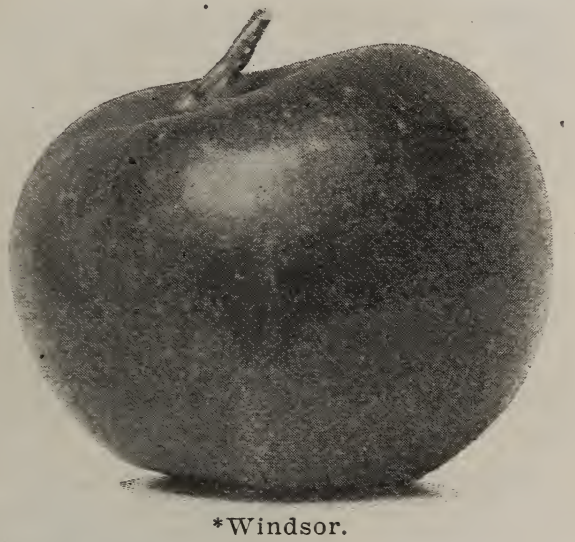

stronger as it attains age. Early annual bearer; very prolific. Winter. Originated in Wisconsin. The highest award was won at the Paris Exposition from apples of this variety, which were grown in our orchards near Arlington.

Wolf River,-Very large and handsome flesh whitish, breaking, pleasant, subacid; poor bearer. November and December. Fruit drops.

Walbridge.-Medium size, striped with red, good cooking; vigorous grower and 
productive; very hardy, and considered of value in the north and northwest. December to January.

Winter Sweet Paradise.-Rather large, roundish, skin pale greenish yellow with brown blush, flesh white, very good flavor, tree upright, bears well, fruit inclined to drop prematurely on some soils. December to January. Hardy in Nebraska.

York Imperial. - Medium, oblate, white, shaded with crimson, flesh firm, crisp, juicy and sub-acid; a good bearer and keeper, one of the best winter apples; moderately hardy. November to April.

\section{CRAB APPLES.}

A good assortment of these trees should be one of the first things planted. They are perfectly hardy and may be relied upon to furnish fruit that can be used for a great variety of purposes. Some of them should be in every collection.

*Briar Sweet.-As large as Transcendent; pale yellow, splashed with carmine; very sweet and rich; fine for dessert or preserves. Tree vigorous and productive.

Gen'l Grant.-Tree a vigorous and upright grower, blights some, fruit large, red to a very dark red, flesh white, tender, mild, sub-acid, excellent for dessert. October.

Hyslop.-Large dark red, sub-acid, bears its fruit in clusters; good eating and cooking; very hardy; subject to blight in some localities, very popular. When over ripe become "floury." September. 
Large Red Siberian.-Large, pale red and yellow; good quality, large tree, with coarse foliage; early bearer, fruit much larger than the common Siberian.

*Martha.-A seedling of the Duchess of Oldenburg, large, striped, very beautiful, as fine as Transcendent. Tree very healthy and handsome; early bearer. September.

Montreal Beauty.-One of the most beautiful of the crabs, fruit large, bright yellow, shaded with red; flesh yellowish, firm, acid; tree a free grower. September.

Sylvan Sweet.-Tree slender, upright, light colored wood, fruit large, pale yellow, with rich blush, flesh white, tender, very good and beautiful. July.

Transcendent.-Yellow, striped with red; good eating, fine for preserving or pickling, good cooking, makes good cider; immensely productive, very early bearer. Blights to death in Nebraska.

*Whitney's No. 20.-One of the largest, glossy green splashed with carmine; firm, juicy, best quality. It is really a choice little dessert apple, perfectly an ironclad; a great bearer. Ripens last of August. Makes a fine white cider.

Yellow Siberian.-Medium size, good quality, tree hardy.

*Florence.-Waxen, yellow and red, medium size; very handsome, perfectly hardy, promises to lead all other crabs.

\section{\& $*$}

\section{Pears}

Pear growing in Nebraska has generally been a failure. Of all the Pears tested here we offer only a few varieties. We 
have faith in a properly selected list of pears when properly cared for. Plant only two or three varieties; try to get well ripened growth, give only fair cultivation with late summer and winter mulching. Coal ashes are particularly valuable as a mulch. Use not less than one-fourth of a wagon load to each tree and repeat as needed. Be content with an annual growth of from twelve to eighteen inches. Rank late growth is often the cause of disease. Plant six inches deeper than stood in nursery.

Bartlett.-Large size; with often a beautiful blush to the sun; buttery, very juicy and high flavored, bears early and abundantly, very popular. August.

Clapp's Favorite.-Very large, yellowish green to full yellow when ripe, marbled with dull red in the sun, and covered with small russet specks, vinous, melting and rich, vigorous. July.

Early Harvest.-Large golden yellow with a fine red cheek, flavor poor, but it sells well in the market because of its size and color and earliness of ripening; ripens one month before the Bartlett. Tree vigorous and productive. Rots at core.

*Flemish Beauty.-Large, red cheeked, beautiful, excellent quality, productive; one of the hardiest; very popular in the west.

Idaho.-Large and handsome, golden yellow, small core; melting and juicy. September to October. Blights to death in Nebraska.

*Kieffer's Hybrid.-This pear was raised from seed of the Chinese Sand 
Pear, accidentally crossed with the Bartlett or some other kind grown near it. Tree has large, dark green glossy leaves, and is of itself very ornamental; is an early and prolific bearer; the fruit is showy and valuable for the table and market and never rots at the core, and is as nearly blight-proof as it is possible for any pear to be. October and November.

*Louise Bonne De Jersey.-Rather large, greenish yellow, with a bright red cheek; juicy, buttery and melting, excellent; very productive; August and September.

*Duchess D'Angouleme Pear.-Very large, dull greenish yellow, streaked and spotted with russet. Flesh white, buttery and very juicy, with rich and very excellent flavor. This variety and Louise Bonne De Jersey when grown as dwarfs are much more profitable than any of the standard sorts. Will bear at two years from planting.

Seckel.-Small, but of the highest flavor; a standard of excellence; a slow grower but bears early. Ripens last of August. Productive.

*Sheldon.-Large, plump, round, russeted; handsome and good; one of the most reliable for Nebraska.

\section{* 4}

\section{Cherries}

A great deal of attention is now given to the growing of Cherries. No home orchard is complete without its proportion of Cherry trees, and it is one of the most profitable of market fruits. It will succeed on any kind of soil that is not wet. 
The Heart and Bigarreau varieties are not very much of a success in the west and southwest; but the Dukes and Morellos succeed everywhere, especially the latter.

Cherries are now generally worked on the Mahaleb, a stock that does not throw up sprouts from the roots.

Baldwin Cherry.-Tree an upright, vigorous grower, forming a roundish head. Fruit large, almost round; very dark; flavor slightly acid, yet one of the sweetest of the Morello type. A promising cherry.

Dye House.- This variety is very much like Early Richmond, a little earlier but not as productive.

*Early Richmond.-Medium, red, fine when well rinened. Tree hardy and very productive. A good tree to plant.

Early Morello.-Believed to ke brought from Germany. Fruit nearly black when fully ripe. Large, tender, rich, vinous. Ripens about with Early Richmond. Bears young and is productive. Is the best quality of any early cherry.

English Morello.-Medium to large; blackish red, rich acid, juicy and good, very productive. July. Should be on every farm in the west.

Terry.-Fruit large, light, brilliant red; becoming darker as it gets riper. The stem is so long that it can be picked from the tree without bruising the fruit. Tree upright, handsome, a fine grower; hardy and very productive. This is one of the coming cherries for the prairies.

Ostheim.-Hardy, productive and vigorous; classed as Richmond. Fruit dark and rich. 
Late Richmond.-(Late Kentish), fruit medium, round, deep red when ripe; very juicy, highly acid; one of the best for culinary purposes; poor bearer.

*Montmorency. - Large, red, acid; larger than Early Richmond and ten days later; prolific and valuable. Quality the very best.

Wragg.-Originated in Iowa; said to be a seedling of English Morello. Med-

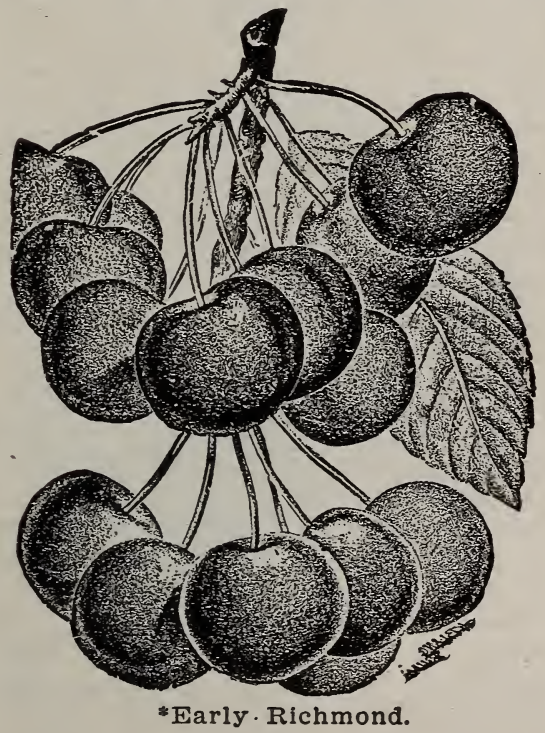

ium to large in size. A variety well adapted for the high altitude and prairie regions of the northwest. July.

Olivet.-A variety of French origin.

The "Star" (*) Varieties are the Leaders. 
Large, globular, very shining, deep red; flesh red, fender, rich and vinous; subacid flavor. Not profitable.

\section{$* *$ \\ Plums}

The best of our natives by careful selection and cultivation are today the most desirable varieties for the planters of the prairie states. They are perfectly hardy, able to stand our climate, and it is from these we must expect our profitable crops of this fine fruit. The plum delights in a cool, not too dry situation, with good, rich soil. The varieties we offer have been thoroughly tested, and are the standbys of the west. These, with the best descendants of the European plums, may be relied upon to furnish yearly crops of this most highly profitable and delicious fruit.

\section{AMERICANA.}

De Soto.-Medium size, resembles Minor in form and color, but two weeks earlier; fine for eating or canning; moderate grower; bears young and profusely; hardy and very desirable; but does not stand extreme drouth well.

Forest Garden.-Medium size, early variety, of good quality; nearly round, mottled red and yellow; sweet and rich; a strong grower. July.

Hawkeye. - Very large, dark red, handsome, rich and good, Tree a moderate grower with broad shining leaves; hardy and profitable.

Klondike.-Medium to large; beautiful yellow, rich and juicy. Tree a good 
grower, very productive and perfectly hardy. Season medium.

* Miner.-Large, red, firm flesh, excellent for canning or cooking; profitable market sort; one of the best if properly fertilized. Tree perfectly hardy.

Pottawattamie-Small to medium size, yellowish red, luscious, good, moderately

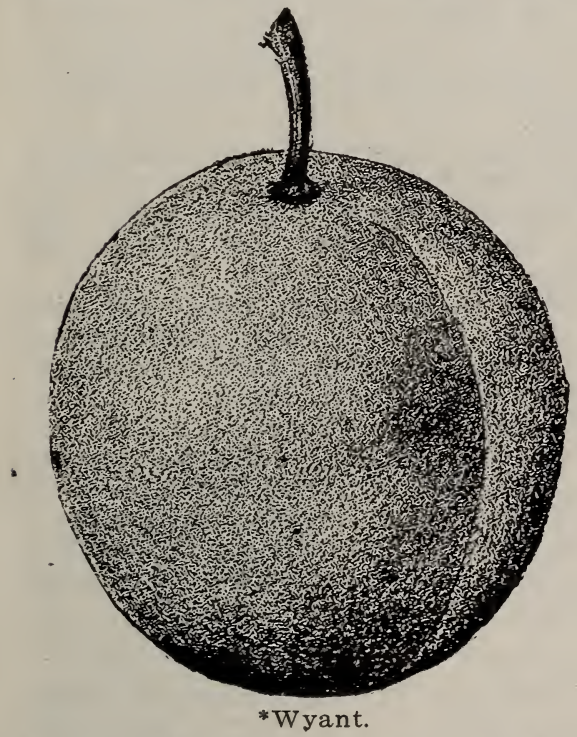

hardy; early and immense bearer; ripens in July. One of the very best for canning.

*Wyant.-Large, round, oblong, purple-red, thick skin, which peels readily; flesh firm; a perfect freestone and of ex-

The ,Star" (*) Varieties are the Leaders. 
cellent quality. Should be more generally planted. Native of Iowa and hardy.

Rollingstone.-Not so large as some, but of the best quality, and covered with such a deep bloom that it looks like a "Blue" plum; perfectly hardy.

Stoddard.-Largest American plum known. It is pure American, but shows strong markings of the Japan type in leaf and fruit. In Iowa the tree is a good, stout grower, beautiful enough for the lawn; an early bearer and perfectly hardy.

* Wolf.-Large, dark red; good quality. Extra fine for cooking and canning. It is a vigorous grower, entirely hardy, and an abundant bearer; one of the very best.

*Wild Goose.-Large, bright red, with purplish bloom, a very good grower; bears early and abundantly; sweet and of very good quality. Early.

Larson Plum.-Originated by Mr. Larson, of Washington County, Neb.; grown from seed brought from Denmark. Fruit very large; dull bluish red; handsome and of the best of quality. Tree perfectly hardy: very productive. One of the coming plums for Nebraska.

\section{EUROPEAN.}

While the European plum is not entirely hardy, still it begins to bear early and bears well up to 12 to 14 years and fruit of the best quality as it matures perfectly and does not rot on the tree as in the east. Please remember the star varieties will ke found the most reliable.

Moore's Arctic. - Medium; purplishblack; juicy and sweet; moderately hardy. 
*Lombar:1.-Large greenish blue, flesh yellowish green; juicy and pleasant. Ripens in August; tree vigorous; one of the most midely cultivated plums of America. A good annual kearer.

*Shipper's Pridle.-Large, nearly round; dark purple. quite jגicy, sweet; splendid shipper, profitable for market. Growth moderate; productive. Originated in northwestern New York.

*Grcen Gage.-Medium size, oval, suture distinct, surface green, slightly tinged with yellow, flesh greenish, juicy, melting, rich, partly free; very good. Tree vigorous, upright, one of the hardiest of the Europeans.

Bohemian Prune.-A very hardy tree and an early and continuous bearer. Fruit of medium size, prune shaped, blue, free stone; much better than German Prune.

\section{JAPAN VARIETIES.}

Burbank.-Large, nearly round, cherry red, with thin lilac bloom; flesh deep yellow, very sweet, of good quality; very handsome; about three weeks later than Abundance. Tree a vigorous grower, and early bearer. One of the best Orientals.

Abundance.- Large, oblong, showy; bright red fruit, with a heavy bloom; flesh orange yellow, sweet, juicy. Tree a strong, handsome, thrifty grower. Commences to bear young. One of the first verieties imported, and the best known and most popular kind. 


\section{Apricots}

Alexis.-Large to very large with red cheek; slightly acid, but rich and luscious; tree hardy and abundant bearer. July 15 th.

J. L. Budd.-Of large size; white, with red cheek, flavor sweet, juicy, extra fine; a hardy strong grower and profuse bearer; the best late variety. August 1st.

\section{$* *$}

\section{The Peach}

The north part of Nebraska is not a Peach country and it is only by painstaking care that we grow even a limited supply of the better class. The peach perfers a well-drained loam. Cut the shoots back one-half every spring, to compel dense growth. Give clean culture. We recommend the following sorts, which we think hardy enough to stand without protection in the southern half of Nebraska. Please remember the * sorts will do best in the greater part of Nebraska.

*Bailey.-An Iowa seedling. Tree dwarfish, spreading willowy habit; peach slightly below medium size, light yellow splashed with red on sunny side, flesh white, best quality, small pit, profuse bearer; has proven to be much hardier than any of the old varieties. Worthy of a trial.

* Bokara No. 3.-Large. Ripens from August 20 to Seytember 10. Free stone; compares favorably with many of the the eastern sorts; was introduced from Bo-

The "Star" (*) Varieties are the Leaders. 
Marshall Bros., Arlington, Neb.

kara, Northern China. Appears hardy, having stood the test of the last ten years in Iowa. They took first premium at the World's Fair as the best peach for the west.

*Champion Peach-Originated in Illinois; fruit large, beautiful in appearance;

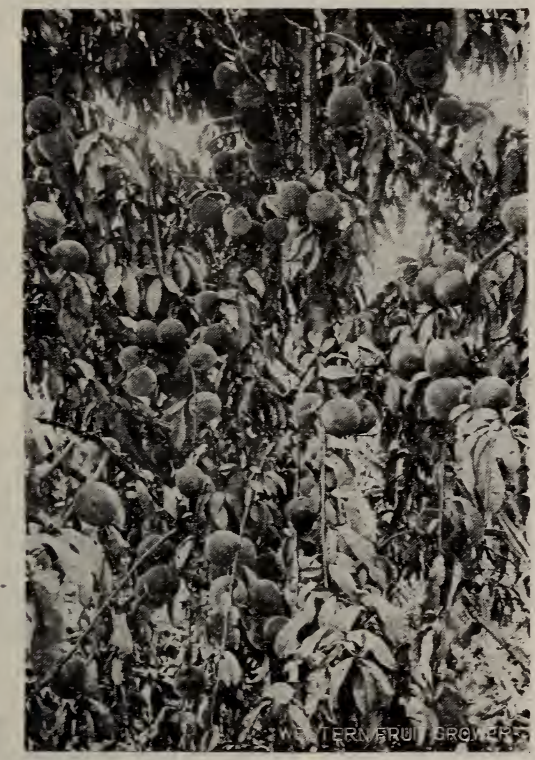

flavor delicious, sweet, rich and juicy; skin creamy' white, with red cheek, becoming quite red when ripe. Freestone; season August. Tree vigorous. One of

The "Star" (*) Varieties are the Leaders. 
the very hardiest and best varieties for Nebraska.

Crosby-Medium; rich orange yellow, with blush; freestone, pit small, flesh yellow, juicy and sweet; tree low, spreading. willowy hakit of growth; perfectly hardy in a peach country.

Elbcrta.-Large, yellow, with red cheek; excellent quality; flesh yellow and melting; freestone; not so hardy as above. September.

Alexander.-Large size, well grown specimens measuring eight inches in circumference, handsome and regular in form, with deep maroon shade, covered with the richest tint of crimson; fair in quality with a vinous flavor; adheres to the stone; should remain on the tree until fully ripe. The earliest peach.

Early Rivers.-Large, light straw color, with delicate pink cheeks; flesh juicy and melting, with very rich flavor. July 20 to August 1.

Hale's Early. - Fruit medium size, skin clean, smooth, white, delicately marbled with bright and dark red on the sunny side; flesh very melting, juicy and high flavored. July 20 to August 1.

Hill's Chili.-One of the most reliable, and hardy, fruit above the average size, quality good.

Wager.-Very large, yellow, more or less colored on sunny side, juicy and of fine quality; free. First to the middle of August. One of the best for the north.

* Vright.-Originated in Nebraska. Similar to Bailey. A good one for $\mathrm{Ne}-$ braska.

*Dunn's Free.-Grown from seed by Mr. Dunn, at Blair, Nebraska. Fruit medium, partly covered with light and 
dark red, quality unsurnassed; rich and melting. Tree appears hardy in Central Nebraska. An early and annual bearer which proves the bud hardy. This bids fair to be the eoming peach in Central Nebraska.

Triumph.-Large, yellow, overspread with red. One of the hardiest and most productive. July 20 to August 10 .

Russell.-Originated by Mr. J. M. Russell, at Wymore, Neb. Fruit large, handsome and very attractive in appearance. Whitish yellow, partly covered with a rich maroon; quality good. Freestone. Tree one of the hardiest; very productive

\section{$* *$}

\section{Grapes}

Everyone may have an abundance of this healthful fruit. The grape is at home in the west. In our deep soils, bright sun and dry atmosphere, it attains its highest perfection. There is scarcely a yard so small, either in city or country, that room for a dozen cr more vines cannot be found, furnishing an abundance for family use. To grow grapes successfully, plant in rich, dry soil.

\section{BLACK GRAPES.}

*Concord.-Bunches large, berries large, round; skin thick and covered with bloom; flesh juicy, sweet. Vine very hardy, vigorous and productive; at present the most popular of all our native sorts.

Champion.-Bunches compact, berries medium, covered with rich bloom, vine a strong and healthy grower and a good 
bearer, profitable for market on account of its earliness. Quality noor.

Clinton.-Bunches medium size, compact, shouldered, berries small, flesh acid, vinous flavor. Vines hardy, vigorous. productive; fruit improves by hanging on the vines; favors wild grapes in vine and in fruit.

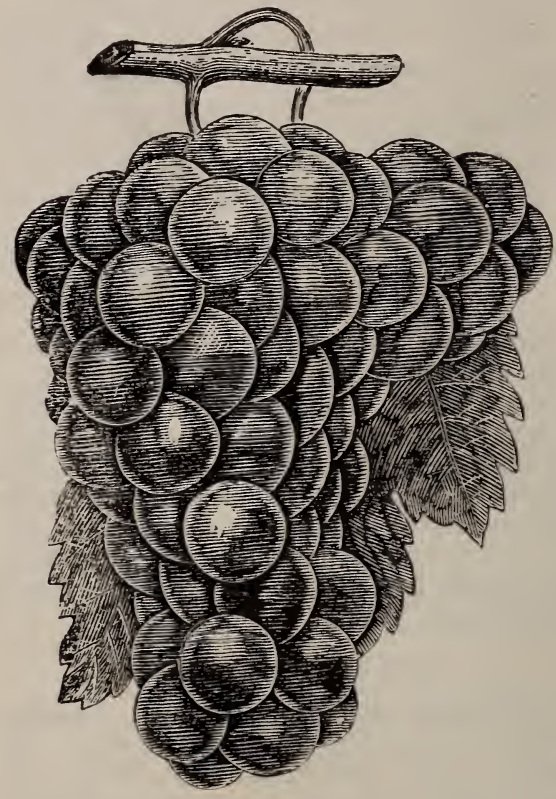

*Worcien.

Herbert.-Bunch large, compact, berry large, tender, sweet and rich, early and productive; a handsome variety. 
Ives.-Hardy and productive; valuable for market on account of its earliness; quality poor.

* Moore's Early. - A large, black grape of the Concord type, the entire crop ripening before the Concord; bunch medium, berries large with blue bloom; flesh pulpy, of good quality. Vine hardy, moderately productive, better as it attains age. Planted extensively as a market sort.

*Worden.-This variety is a seedling of Concord, which it greatly resembles in appearance and flavor, but the berries are larger, the fruit is better flavored and ripens several days earlier.

Campbell's Early.-Bunches medium to large, berries large, glossy, black with a beautiful blue bloom. Pulp sweet and juicy. Good. Seeds small and few in number. Season ten days earlier than Concord. New and promising.

\section{RED GRAPES.}

McPike.-Originated in Southern Illinois. Has taken premiums at many state fairs. Is a seedling of the Worden: a little earlier than the Concord. Bunches large, even and compact. Berries large and covered with a blue black bloom. New but promising.

Agawam.-Large, round, early, and of great vigor of growth; rich, high, peculiar aromatic flavor; very desirable; should be covered in winter.

* Brighton.-A cross between Concord and Diana Hamburg; bunches large, berries of medium size; flesh sweet, tender,

The "Star" (*) Varieties are the Leaders. 
and of the highest quality; ripens early; purple.

Delaware.-Still holds its own as one of the finest grapes; bunches small, compact, shouldered; berries rather small, round; skin thin; flesh very juicy, without any hard pulp; an exceedingly sweet, spicy and delicious flavor; vine moderately vigorous; very productive; should be covered in winter.

Wyoming Red.-A very early, medium size, red variety; bunch small but compact; skin bright red; sweet; very agreeable were it not for the slight foxy odor apparent when first gathered.

\section{WHITE GRAPES.}

*Elvira.-Ripens about with Catawba; a very strong, healthy and robust grower; very productive; bunch and berry of medium size and very compact; quality medium.

Empire State.-Rickett's)-A seedling from Hartford Prolific, fertilized with the Clinton, bunches large, long, shouldered; berry medium to large; flesh tender, juicy and rich, with a slight native aroma; ripens very early and continues a long time in use; should be covered in winter.

Goethe-(Rogers' No. 1)-This is for the west decidedly the best of all the Rogers' Hybrids. Pale red, with beautiful bloom when fully ripe; thin skin; tender pulp; very juicy, sweet and delicious; ripens after Concord; very fine for market and table; does better when covered in winter.

Moore's Diamond.-Very hardy, early and vigorous; ripens two weeks earlier than Concord. 
*Golden Pocklington-Is a seedling from Concord; vine hardy, both in wood and foliage; strong grower; called a white grape, but the fruit is a golden yellow: clear, juicy and sweet to the center, with little or no pulp; bunches very large, sometimes shouldered; berries round, very large, and thickly set; quality, when fully ripe, much superior to Concord, perfectly hardy.

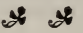

\section{Mulberry}

Russian-Valuable for hedges and wind break around orchards and fruit plantations, as it bears every year, ripening constantly nearly all summer, thus feeding the birds. A necessity.

Downing Mulberry-(Downing's Everbearing)-Color blue black; flesh juicy, rich, sugary, with a sprightly vinous flavor; tree ornamental as well as fruitful. Not quite hardy in Nebraska.

\section{* $*$ \\ Juneberry}

Dwarf-Grows four to six feet high; bunches out from the ground like currants; resembles the common Servis or Junekerry in leaf and fruit, but the fruit is larger, and in color almost black; commences to bear the second year after transplanting. and bears profusely. No farm or garden should be without this most excellent dessert.

\section{Nut Trees}

Black Walnut-This is the most valuable of all our timber trees for planting; 
a moderate grower, producing a large nut. The timber enters more largely into the manufacture of furniture and cabinetware than almost any other, and is prized almost with mahogany.

Chestnut - (American) - Our native species; smaller than the Spanish, but sweeter; moderately hardy.

Butternut-(White Walnut)-A fine native tree, producing a large, longish nut, which is prized for its sweet, oily, nutritious kernel.

\section{* * \\ Blackberries}

Plant in rich soil and a little shade,

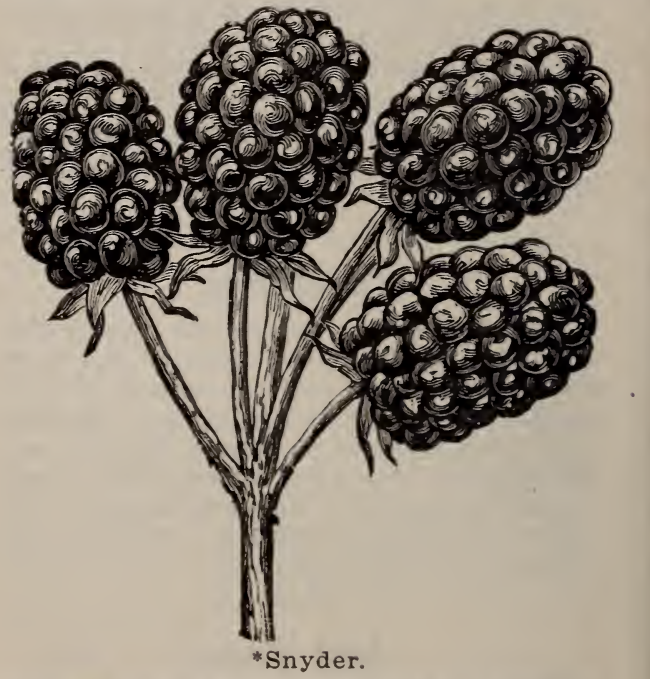

among trees, or on north side of trees or fence, if possible. 
*Snyder-Medium in size, sweet and good, strong grower, very productive, extremely hardy; has fully proven its value, and should be universally planted.

Stone's Hardy - It is a vigorous grower; berry glossy black and of good flavor; a little later than Snyder.

Taylor-One of the largest Blackberries grown; fruit of the best quality, melting and without core; very productive; nearly as hardy as the snyder, which renders it very valuable.

Dewberry-(Lucretia) - This is the finest of its class, one that has proved successful; a strong grower. It is really a new trailing blackberry, easily protected in winter. Set the plants two feet apart in the row; cover in winter with coarse litter and mulch the plants with it in the spring, thus keeping them off the ground.

\section{$* 2$ \\ Raspberries}

Plant on strong soil, manure freely, cultivate well and mulch heavily.

\section{BLACK RASPBERRIES.}

Gregg-The leading late Black Cap, and a popular variety. Canes of strong, vigorous growth, and under good culture very productive; berries are large, cov ered with heavy bloom, firm, meaty and of fine flavor; it requires a good, strong soil to produce the best results; it is not entirely hardy, but suffers during unusually severe winters; it is by far the best late Black Cap of any of the old sorts. 
Kansas-Originated in Lawrence, Kansas. It is healthy, vigorous and not subject to leaf blight; produces strong. healthy tips; fruit large; as fine a berry as Gregg, and a good shipper; ripens just after the Souhəgan; very prolific.

*Nemaha-This fine berry originated in Nemaha county, Nebraska-a seedling of the Gregg, and is almost identical; fruit a little later and of better quality; stands more upright, and is much hardier; thus a ketter kerry for dry prairies.

Older-Originated in Iowa fifteen years ago, and has stood all our severest winters. Coql black, about as large as Gregg, and five days earlier. A very reliable variety, and profuctive; stood the drouth of 1894 and 1895 better than any other variety on our plantation, it being the only one to produce a paying crop in 1896: Nemaha was the next, however.

*Palmer-Early, ripening with Souhegan, but larger and more productive; has - borne more quarts per acre on our grounds than any othor variety; the canes are hardy and berries of good quality.

Trler-(Souhegan)-A leading early market variety, ripening its entire crop in a very short time; medium size, very black, without bloom; flesh firm and sweet; plant vigorous, strong, hardy, but runs out in five or six years, and should be renewed.

Golden Queen-Similar to Black Cap, only yellow in color; a curiosity.

\section{RED RASPBERRIES.}

Cuthbert-(Or Queen of the Market)Berries very large, rich crimson, very handsome, and so firm that they can be shipped in good condition; flavor sweet, 
rich and luscious; should be covered in winter.

Turner-A beautiful berry, of fine size and excellent quality; one of the hardiest and most productive varieties known.

Cardinal-A very promising new cross between the red and the black. Thrifty and productive; quality good.

\section{$*$}

\section{Straloberries}

The Strawberry has been styled the queen of fruits. It is the first to ripen and the quickest to come into bearing. Can be successfully grown on a great variety of soils; responds readily to kindly location and liberal feeding and culture. Every home builder who fails to have an abundance of this delicious health-giving fruit, misses a chance of great things for little money. The strawberry prefers a cool, moist soil. Not subject to drouth; good upland soil is the best, well enriched.

Of the hundreds of varieties that have been introduced we offer only a small number of the best. Be sure to note the star (*) varieties.

*Beder Wood-This has been well-tested all over the country, and holds first place as a good fertilizer for most pistillates, and one of the best bearers of excellent fruit of good size and quality; commences ripening early and lasts a long time.

Captain Jack-Another old standard variety. This is a very good one, but of late years it seems more subject to rust, or leaf blight, than any of the above,

The "Star" (*) Varieties are the Leaders. 
hence, in hot, dry seasons, it doesn't produce the crop that Wood or Robinson does. You must be careful not to allow plants to set too thick in the row or your fruit will be small and inferior.

*Crescent-This is an old standard variety we have had for many years. It is still a good one. However, we think the Warfield will give better satisfaction.

*Dunlap-Originated in Illinois. One of the best of all around rarieties ever

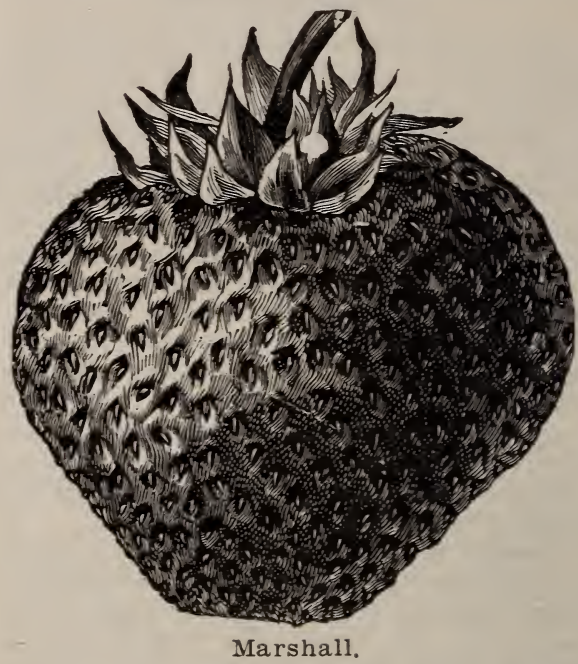

introduced, of the Warfield type; has a perfect blossom, is hardy and productive; is able to hold its own under any rough and tumble treatment, bringing every berry to maturity. Fe believe this to be one of the greatest berries ever introduced.

Gardner-This is a natural production 
of Iowa; found growing wild in a cedar grove, near the north line of the state. It produces an abundance of pollen; fruit stalks very heavy and strong; plants stocky and large, berry is shaped like Crescent, but very much larger; the average berries will measure from one to one and one-fourth inches in diameter. Bright red in color and holds its size up to last picking; flavor rich and good; very productive, and makes plenty of good, strong plants; very hardy.

Marshall Strawberry - Very large, roundish, dark, rich crimson; quality very good; firm; plant vigorous, productive; season medium to late.

Parker Earle-Under favorable circumstances this is one of the most productive berries, but it sets such an enormous crop of berries that it must have rich soil, high cultivation and plenty of water from blossoming time until fruit is ripe, for it to mature its crop. Handsome; quality good. It makes but few plants, but they are very large. We plant it about ten inches between plants in the row, and that distance apart makes a good fruit-growing row.

Robinson-This originated in Kansas; one of the best as a fertilizer for the pistillates, as well a producing an excellent crop of berries of good size and quality; plant and foliage very much like Crescent.

* Sample-Extremely productive when planted with Dunlap or some other staminate variety; perfectly hardy and stands drouth well; fruit firm, medium to large; dark color; very good; one that can be relied upon.

*Warfield-We place this at the head 
of the list of valuable berries because, after being well tested over about every state in the union, it is considered one of the best (if not the best). berry grown, all things considered, that go to make a profitable berry. Four rows of this with two rows of B. Wood as a fertilizer will produce more good, marketable fruit on our grounds than any other we can now name.

Splendid-This kerry continues to keep up the record that gave it its name. Plants healthy and productive; berry larger than Crescent, better quality and a better shipper.

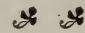 \\ Currants}

Every family should have a good supply of this beautiful, easily grown fruit. Currants love a cool, deep soil, and a little shade. Among fruit trees or along the north side of a fence is a good place. No matter how good the soil, give good cultivation and plenty of manure. The following varieties will give good satisfaction:

*Victoria-Large, bright red; bunches very long; late; very productive and valuable. This is a standard, very good and reliable currant, and will suit everybody.

Cherry-Well known; large, bright, crimson; very acid; an old favorite; one of the largest currants.

Red Dutch-An old favorite;productive and of good quality; fruit small.

Fay's Prolific-Very prolific if properly cared for. It is a gross feeder, and requires liberal fertilization. It is healthy, vigorous and very productive; bunches long, easily picked; commands a high 
price; berries large, and hold their size well to the end of the bunch; bright red, of good flavor, and more acid than most varieties.

*White Grape-Very large, white; this is the very kest table variety of currants known; sweet or very mild acid; good grower, hardy, perfectly satisfactory in most respects, and a currant we most heartily recommend for any purpose.

White Dutch-White; medium size; vigorous grower and good bearer; bunches very compact; early. Fruit requires less sugar than some others, and is excellent for jelly.

Red Cross-Large red variety. Seems to be very prolific and perfectly hardy; comparatively new in Nebraska.

North Stal-Both berry and bunch are very large; the fruit is superior, very sweet and rich in quality, firm, a very good market currant; desirable as a dessert fruit in the natural state, and unequaled for jelly.

\section{* 2}

\section{Gooseberries}

In order to produce large, abundant crops of gooseberries, it is necessary to manure heavily and prune closely; they require about the same location, treatment, etc., as the currant.

Pearl-Fruit and bush similar to Downing; kears well and is perfectly hardy. Is one of the newer sorts.

*Houghton-The old well known sort; pale red; quality good. It is rather small but a productive, healthy and very reliable gooseberry.

The "Star" (*) Varieties are the Lcaders. 
Smith's. Improved - Much like the Downing; strong grower; large berry; productive.

Industry-Very large; dark red; hairy; of delicious quality. In a cool, rich soil, with a northern exposure, it will yield a few large, luscious berries; it is a little impatient of the hot sun; not an ironclad.

*Downing - Fruit very large; flesh whitish green, soft, juicy and good; plant

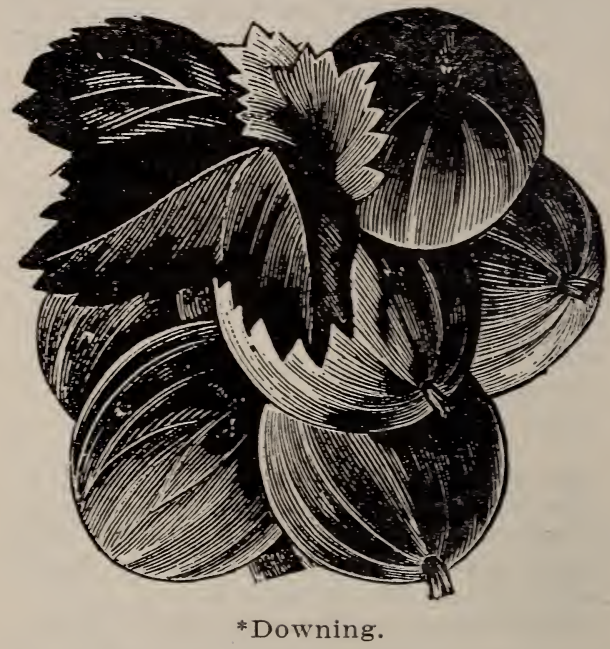

vigorous and prolific; one of the very best.

*Champion - Medium to large size; quality good; free from mildew; bush large and healthy; very productive.

The "Star" (*) Varieties are the Leaders. 
Marshall Bros., Arlington, Neb.

\section{Asparagus}

* Conover's Colossal-Is the best for general planting, and is largely grown.

Palmetto-Early; is a very reliable variety.

\section{* * \\ Rhubarb}

*Victoria-Very large, long stems; fruit tender.

Linnaes-Early, tender and good; season long.

\section{$*$}

\section{Ornamental Department}

Suggestions to Planters.

The extremes in temperature in this country are so great, and the changes so sudden, that it is safe only to plant the most hardy ornamental trees and shrubs. The varieties that will grow in the nursery when young without protection in winter may be regarded as safe to plant in parks and extensive grounds as well as in lawns and small places. Yet a few of the most beautiful sorts are not perfectly hardy and will be greatly benefited by some protection during the severe winters. A judicious selection from the many varieties given in this catalogue will enable the planter to accomplish his desire in securing that which will give him satisfaction both in hardiness and in effect.

For Lawns and Small Places-A little more care may be taken in making selections for this purpose, although the selections will depend very much on the size of the ground to be occupied. Where only a few trees and shrubs can be plant- 
ed, the medium or small growing sorts, and those that display the finest appearance both in foliage and flowers should be used, while on larger places a much more extensive assortment can be planted.

\section{$* *$ \\ Deciduous Trees}

*Ash, American White-A medium grower and valuakle for planting in the street or in parks: may be extensively planted for timber.

Ash, Mountain European-(Sorbus aucuparia)-A very beautiful tree of medium size, with an erect stem, smooth bark and round head; covered during the fall and winter with bright scarlet berries, and is universally admired.

*Ash, Mountain American-A tree of rapid but coarser growth than the European variety; pinnate foliage.

Ash, Mountain Oak-Leaved-A handsome tree of erect habit and rich green foliage, deeply lobed; hardy and desirable.

Birch, American White-A beautiful native tree, common to our woods, particularly in the northern part of the country; its shining white bark and slender brown branches make it an attractive object; foliage large, handsome.

*Birch, European White-A wellknown tree, with graceful, airy foliage and silvery white bark; very desirable for the lawn, either as a single specimen or in contrast with other trees in a group.

Birch, Cut-Leaved Wecping - See Weepers. 
Catalpa Speciosa-A variety originating in the West; more upright and symmetrical in its growth than the common Catalpa, and blossoms two or three weeks earlier. Valuable for timber, fence posts, railroad ties, etc., possessing wonderful durability; a very ornamental and valuable tree where hardy.

Chestnut, Amcrican White-See Nut Trees.

*Cherry, Wild Black-A beautiful, upright, round headed, strong growing tree; slender, glossy leaves; hardy.

*Elm, White-(Ulmus Americana)-A noble spreading and drooping tree of our native forests, peculiarly suitable for avenues and drives, where it is at once useful and ornamental.

EIm, Camperdown Weeping - See Weepers.

Hor'se Chestnut, European-Similar to the American Buckeye; forms a round, shapely head; very dense and beautiful; moderately hardy.

Linden-A rapid growing, large sized tree, with a remarkably straight trunk; deep green, heart-shaped leaves, and clusters of fragrant yellow flowers; makes a handsome shade tree.

*Maple, Soft or Silver-Leaved-Of rapid growth; of great value where a rapid growing tree is desired; very hardy and easily transplanted; a favorite street or park tree.

Maple, Norway-Spreading, rounded form; foliage large, dark green; a beautiful shade tree.

Maple, Hard or Sugar-A beautiful, stately tree of fine form; a desirable shade tree where it does well.

The "Star" (*) Varieties are the Leaders. 
Maple, Ash-Leared-(Box Elder)-A rapid growing variety, with handsome, light green foliage and spreading head; a free grower and very desirable as a shade tree; does better on low land.

Mulberry-See Fruit Department.

Mulberry, Tea's Weeping-See Weepers.

* Olive, Russian-An ornamental tree of special value; attains a height of thirty feet or more; bark and leaves light green when young; bark becomes darker as the tree grows older, and the leaves more silvery white; blooms profusely in June in small racemes, three inches long, and their fragranze decidedly sweet and spicy. an excellent lawn tree.

Pin Oak-One of the most beautiful street and lawn trees grown; of rapid growth, and transplants much easier than the Burr Oak; perfectly hardy.

Poplar, Silver Leaved-A tree of remarkably rapid growth; at a distance the white under surface of the leaves turned up to the wind gives it somewhat the aspect of a tree covered with white blossoms.

Sycamore-American Plane or Button Wood-A well known tree, and one that is well adapted for streets in cities and villages, where gas and smoke are injurious to foliage; upright, shapely and beautiful.

Poplar, Lombardy-Very upright; a beautiful tree if headed back.

*Poplar, Carolina-Of good form and robust growth, and desirable where a very large tree is required; a beautiful lawn tree if cut back to eight or ten feet.

Tulip-A native tree of the Magnolia order; rich, glossy foliage; regularly dis- 
tributed branches and large tulip like flowers; difficult to transplant unless of small size.

Walnut, White or Black-See Nut Trees.

\section{$* *$ \\ Weeping Trees}

*Birch, Cut-Leaved-An elegant, erect tree, with slender, drooping branches and fine cut leaves; a magnificent variety and worthy a place on every lawn; hardy.

Elm, Camperdown-Its vigorous, irregular branches, which have a uniform weeping habit, overlap so regularly that a compact, roof-like head is formed; the finest Weeping Elm.

*Mulberry, Tea's - A graceful and beautiful hardy tree, forming a perfect umbrella-shaped head, with long, slender, willowy branches, drooping to the ground and gracefully swaying in the wind; foliage small, lobed, and of a delightful, fresh, glossy green. The tree is exceedingly hardy, of rapid growth and abundant foliage; it is admirably adapted to cemetery planting and susceptible of being trained into almost any shape.

Mountain Ash-A beautiful tree, with straggling, weeping branches; makes a fine tree for the lawn; suitable for covering arbors; hardy.

Willow, Wisconsin Weeping - Our common and well known Weeping Willow.

Willow, Kilmarnock-An exceedingly graceful tree, with large, glossy leaves; one of the finest of this class of trees.

*Thurlow Willow-A very handsome, 
rapid growing weeping tree; will make a large tree in a very few years; hardy.

New American Willow-An American dwarf; slender branched species; when top worked five or six feet high, makes a beautiful small tree.

Maple, Weir's - A handsome, cutleaved weeping tree of the maple variety; hardy.

\section{$* 2$ \\ Shrubs}

Almond, Flowering-Beautiful shrubs, with small double, rose and white blossoms, set closely upon the twigs before the leaves appear; white and pink.

Berberry, Common-A nice shrub, with yellow flowers in drooping racemes in May or June, and followed with orange scarlet fruit.

*Berberry, Purple Leaved-An interesting and beautiful variety, with violet purple leaves and fruit; a splendid hedge plant.

Calycanthus-Sweet scented; an interesting shrub, having a rare and peculiar fragrance of wood and flowers; its blooms are abundant and of a peculiar chocolate color.

*Honeysuckle, Tree-A well known shrub whose bright pink flowers appear in May.

* Hydrangea- (Paniculata grandiflora) -A fine shrub, blooming from July to November; large, showy panicles of white flowers in the greatest profusion; it is altogether a most admirable shrub for planting single on the lawn or in the margin of masses; to produce largest flowers

The "Star" (*) Varieties are the Leaders. 
it should be pruned severely in the spring and the ground enriched; perfectly hardy.

Lilac (Svringa) Persian-Native of Persia; from four to six feet high, with small foliage and bright purple flowers.

Lilac, Common Purple-Bluish purple flowers.

Lilac, White-A beautiful variety; has very large, pure white panicles of flowers.

*Snowball-A well known favorite

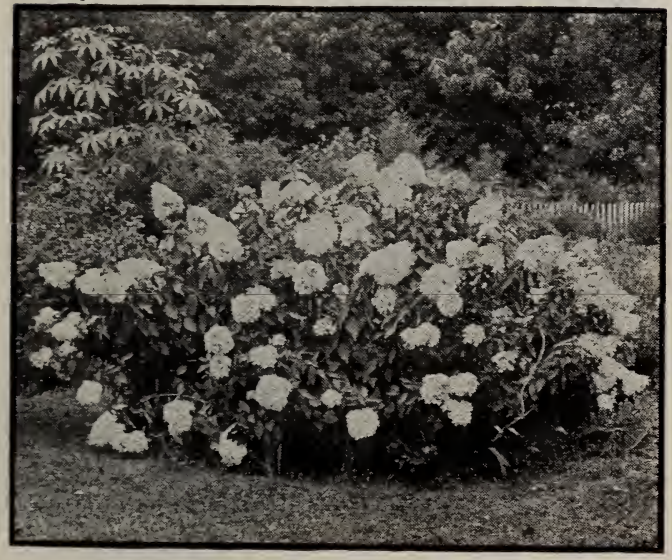

*Hydrangea at Nurseries.

shrub, of large size, with globular clusters of pure white flowers the latter part of May; perfectly hardy.

Spirea Anthony Waterer-This beautiful variety has the same habits as its parent, the Bumalda. It blooms about the close of June, continuing throughout the entire season. It is useful for edg- 
ing, planting in masses, or as a single specimen when a low bushy shrub is required.

*Spirea, Van Houtii-Graceful, with long, drooping sprays, studded thickly with handsome, pure white flowers,

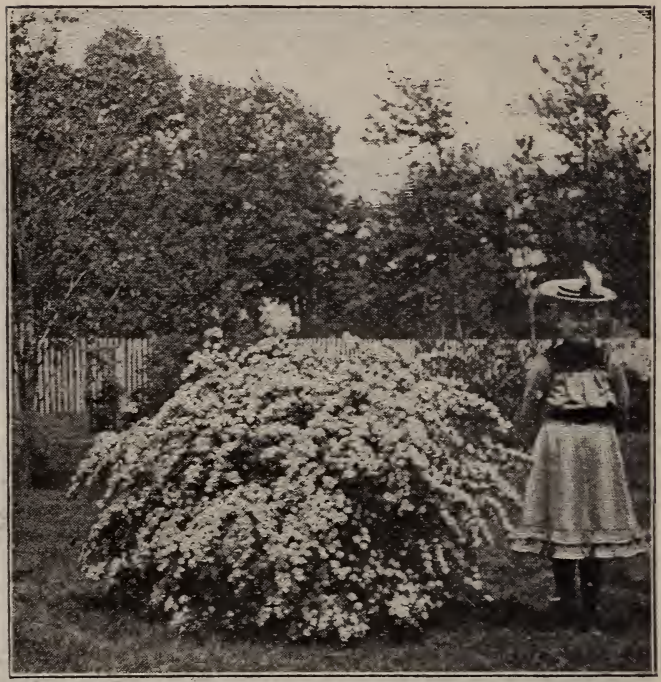

*Spirea, Van Houtii at Nurseriss.

hence the name "Bridal Wreath;" the grandest of all; perfectly hardy.

*Syringa (Philadelphus) Grandiflorus -A conspicuous, showy variety of the Syringas, with large, waxen white flowers; perfectly hardy and reliable.

Tamerix Amurensis - (Russian) - A very rapid growing, handsome shrub; should be in every yard. 


\section{Vines and Creepers}

*Clematis Jackmanni-A very profuse blooming variety, with flowers from four to six inches in diameter, of an intense violet-purple color, borne successively in continuous masses on the summer shoots.

*Clematis Paniculata-We fail to find words to describe this beautiful Clematis to our satisfaction. Its dark green foliage and white flowers produce an effect that will astonish any one, no matter how flattering a description they have had of it. Is a very thrifty grower and perfectly hardy, often covering a large window in two seasons; begins blooming in August and remains in bloom a long time; very fragrant.

Clematis, Henryi-New, and one of the the best perpetual hybrids, of a robust habit, and a very free bloomer. The flowers are white, large and very showy. July to October.

Clematis, Virginia-One of the most rapid growing kinds, covered in August with the greatest profusion of pure white fragrant flowers, which are succeeded by brown, hairy-like plumes; very beautiful and unique.

Honeysuckle, Yellow Trumpet - A well known variety, with yellow trumpet flowers.

*Honeysuckle, Scarlet Trumpet-This and its varieties are the handsomest in cultivation; it is a strong, rapid grower, and produces scarlet inodorous flowers all summer.

The "Star" (*) Varieties are the Leaders. 
Honeysuckle, Halliana-(Hall's New) -Nearly evergreen; flowers pure white, changing to yellow; producing abundantly; fragrant like a jessamine; the best bloomer of all.

\section{Ampelopsis Quinquefolia - (Virginia} Creeper)-A native vine of rapid growth, with large, luxuriant foliage, which in autumn assumes the most gorgeous and magnificent coloring; perfectly hardy; the best climber for Nebraska.

Wisteria-A most beautiful climber, of rapid growth, and producing long pendulous clusters of pale blue flowers; when well established makes an enormous growth; is very hardy, and is one of the most superb vines ever introduced.

\section{\& $\$$}

\section{Roses}

They will repay good treatment. The feeble, sod-bound plants cannot give free bloom. Mulch well with manure. All Climbing Roses in this climate are benefited by being laid down and covered in winter.

\section{Climbing Roses.}

Nothing can cover an arbor or veranda or form a more beautiful screen for an unsightly object so charmingly as a climbing rose; needs but one planting, and increases in keauty as years go by.

Baltimore Belle-Pale blush, shading to rose color; very double; flowers in beautiful clusters, the whole plant appearing a perfect mass of bloom; one of the best climbing roses, must be protected in winter.

The "Star" (*) Varieties are the Leaders. 
Marshall Bros., Arlington, Neb.

*Prairie Queen-Clear, bright carmine pink, sometimes with a white stripe; large, compact and globular; blooms in clusters: the best hardy climber, except Crimson Rambler, in this climate.

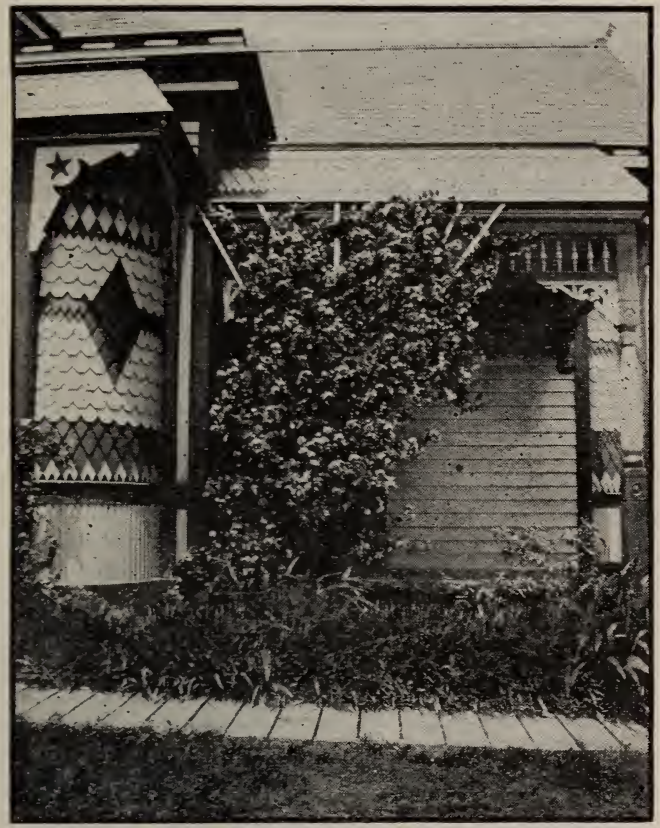

*Prairie Queen.

Seven Sisters-Blooms in large clusters, with flowers varying from white to crimson; dark green foliage; should be protected.

*Crimson Rambler - This beautiful climbing rose is surely deserving of much 
praise. The plant is a vigorous grower, making shoots eight to ten feet long in a single season; a very desirable climber for covering trellises, verandas or arbors; blooms early in the season; the flowers with which the plant is covered are produced in the brightest trusses of very bright crimson color, making a most beautiful appearance when in bloom.

\section{Yellow Roses.}

Harrison's Yellow-A beautiful small yellow June rose, perfectly hardy.

*Persian Yellow - Perfectly hardy; flowers double and full, deep golden; blooms freely in June; the finest hardy yellow rose grown, and not supplanted as yet by any modern introduction.

\section{Hybrid Perpetuals.}

These are hybrid crosses between June and monthly roses, partaking of the hardiness of one parent and the perpetual blooming habits of the other. They are by far the most popular family of roses. As all hybrid roses bloom on new wood only, they should be cut off from 8 to 10 inches above the ground each spring, thus they will send up good strong shoots each spring, which will prođuce much larger bloom than will the weak slow growth of the old wood if left untrimmed. Clipping off of the seed pods will also aid in the blooming. They should be protected in winter by throwing a mound of earth around them ten or twelve inches high during the fill, removing same in the spring.

The "Star" (*) Varieties are the Leaders. 
Coquette Des Alps - White, lightly shaded with carmine; of medium size; a free bloomer.

* General Jacqueminot-This might be called the rose for the million, for it is still a universal favorite; bright crimson scarlet, exceedingly rich and velvety. Grown more extensively than any other rose; one of the hardiest.

General Washington-Color brilliant crimson; very rich and beautiful; large, perfectly double and a free bloomer.

Madam Chas. Wood-One of the most beautiful hybrid perpetual roses ever introduced; the flower is extra large, full and double; color deep rosy crimson, sometimes brilliant scarlet, with maroon shading; blooms soon after planting out and continues to bloom all summer.

Fisher Holmes-Bright red, beautiful; double; free bloomer.

John Hopper-Rose with crimson center; splendid; fragrant and very desirable.

* Magna Charta - A splendid sort; bright, clear pink, flushed with violet crimson; very sweet; flower extra large, fine form; very double and full; a free bloomer.

*Mad. Plantier-Pure white; large, very double flower; perfectly hardy; suitable for hedge planting; foliage small; blooms early; one of the very best white roses; blooms on old wood, but does not need covering in winter.

*Paul Neyron-Flowers of immense size, often five inches in diameter; color deep, clear rose; very fresh and pretty; the plant is a strong, healthy grower, with clean, glossy foliage, and one of the most constant and prolific bloomers in 
the hybrid class; young plants in the nursery row bloom almost without intermission from June to late October.

Prince Carmille De Rohan-Deep relvety crimson; large, moderately full; continues to bloom all summer; a splendid rose.

\section{Moss Roses.}

The Moss Roses are strong growers and perfectly hardy. They remain in bloom a long time, and are greatly prized for their beautiful mossy buds.

Countess of Murinais - The finest white moss rose; large, very beautifully mossed.

Glory of Mosses-Pale rose, very heavily mossed; one of the best moss roses in cultivation.

*Luxembourg - Large, cupped ; fine purplish crimson; a luxuriant grower and free bloomer.

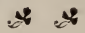

\section{Paeonies}

Paeonias-It is surprising that so noble a flower, almost rivaling the rose in color and perfection of bloom, should be so neglected. It succeeds everywhere, and with but little care may be kept entirely free from disease and insects. Blooms every year. Flowers very large, and may be had in the different colors, as follows: Pure white, cream (light), rich cream or almost yellow, the different shades of pink, light red and deep, rich red. Perfectly hardy anywhere in the West. 


\section{Bulbs}

Dahlias-(Double)-Well known autumn flowering plants, growing from two to five feet high, and producing a profusion of flowers of the most perfect and beautiful forms, varying in color from the purest white to the darkest maroon.

Yucca-(Filiamentosa) - This beautiful and interesting plant should be in every collection. It grows in clumps, and when about to bloom throws up a flower stock from three to four feet in height, from which hang from 100 to 200 creamy white, bell shaped flowers. It remains in bloom a long time.

\section{* $*$}

\section{Ebergreens}

A few varieties of Evergreens, judiciously selected and properly planted, will prove perfectly hardy and very satisfactory.

*Austrian, or Black Pine-(Austriaca) -A native of the mountains of Syria; a rapid growing species, with long, stiff, dark green leaves; very hardy; does well on the high prairies.

* Scotch Pine-(P. Sylvestris)-Native of the British Islands; very rapid in growth; "a dark, tall evergreen," with a bluish foliage and rugged shoots; hardy, and grows well even in the poorest soils.

White Pine-(Strobus)-The most ornamental of all our native pines; foliage light, delicate or silvery green; flourishes in the poorest soils.

Norway Spruce-A lofty, elegant tree, of perfect pyramidal habit; remarkably 
elegant and rich; and as it gets age, has fine, graceful, pendulous branches. It is exceedingly picturesque and beautiful.

*White Spruce-A tall tree, with compact branches and light green foliage; hardy.

Arbor Vitae-This is one of the finest medium-sized evergreen trees; one of the best and most available of the evergreens for screens. It is a native of the coldest part of the country, and there are few places where it will not thrive. Used more than any other variety for ornamental hedging. By the proper use of the knife and shears it can be made to grow into almost any desired form.

Balsam Fir-A very regular, symmetrical tree, assuming the conical form even when young; leaves dark green above, silvery beneath; very ornamental while young.

Swedish Juniper-A small sized, handsome, pyramidal tree, with yellowish green foliage.

Savin Juniper-A low, spreading tree, with handsome dark green foliage; very hardy, and suitable for rock work and low hedging.

\section{WESTERN AND ROCKY MOUNTAIN EVERGREENS.}

Colorado Blue Spruce-(Picea pungens;-This species has been tested at various points on the prairies of the West and Northwest with perfect success. This is not only one of the hardiest, but the most beautiful in color and outline; foliage of a rich blue or sage color. It is a valuable acquisition. 
Marshall Bros., Arlington, Neb.

* Black Hills Spruce-Compact, shapely and of deep green color. As the name would imply, it is a native of the Black Hills, hence naturally adapted to dry weather and high altitude. It is one of the very best for Nebraska and South Dakota.

Dwarf Mountain Pine-(Mughus) - A very distinct species; leaves short, stiff, a little twisted, and thickly distributed over the branches; does not grow large; but spreads over the ground, generally assuming a globular form; very dense.

\section{LIST FOR HEDGES.}

\section{Deciduous Trees}

Barberry, common

Barberry, purple leaf Black Hills Spruce Osage Orange

Russian Mulberry

Tamarix Amurensis

Honey Locust

\section{- Norway Spruce}

\section{Evergreens}

Arbor Vitae

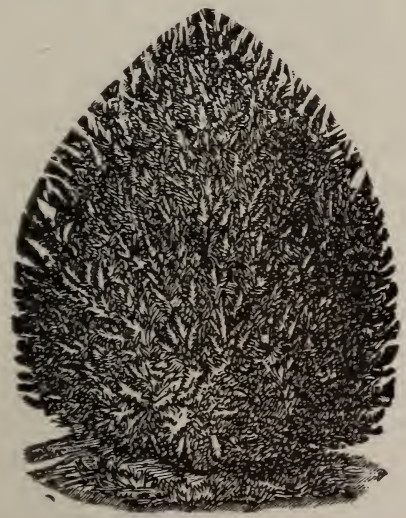

The "Star" (*) Varieties are the Leaders. 


\section{Index}

Page

What Some of Our Customers Say... 1-3

Letter to Customers, etc............. 3

Preface ........................... 4

Advice to Correspondents ............ 5

Guarantee of Genuineness............ i

Number of Trees, etc., per acre ....... 6

Directions for Transplanting, Care,

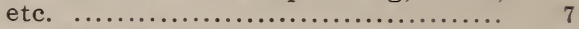

Care When Received from Nursery... 8

For Planting Fruit Trees, etc....... 8-13

How to Winter Trees Received in the

Fall ................................ 13

Spraying Formulaes ................14-17

Summer Apples .................... 19

Autumn Apples .....................21-23

Winter Apples .......................24-30

Crab Apples ...................... 30

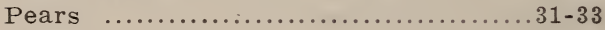

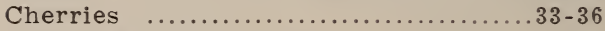

Plums, Americanna ............... 36

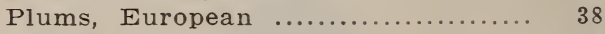

Plums, Japan ..................... $\quad 39$

Apricots .......................... 40

Peaches ...........................40-43

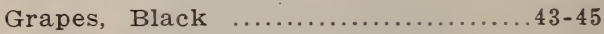

Grapes, Red ..................... 45

Grapes, White .................... 46

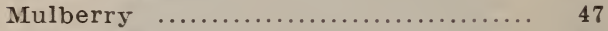

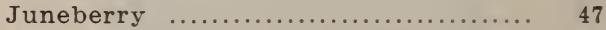

Nut Trees ...................... 47

Blackberries ....................... 48

Raspberries, Black ............... 49

Raspberries, Red ................. 50

Strawberries ...................... 51-54

Currants ............................ 54

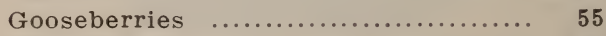

Asparagus ...................... 57

Rhubarb .......................... 57 
Ornamental Department, Suggestions 57

Deciduous Trees ....................58-60

Weeping Trees .................... 61

Shrubs, Ornamental ...............62-64

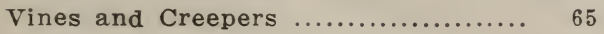

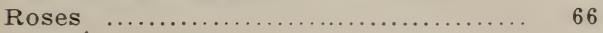

Roses, Climbing .................. 66

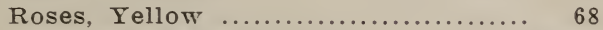

Roses, Hybrid Perpetual ............68-70

Roses, Moss .......................... 70

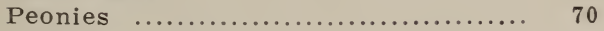

Bulbs .............................. 71

Evergreens ......................... 71

Evergreens, Western and Rocky

Mountain ......................... $\tau^{2}$

Hedges, List for ................... 73 



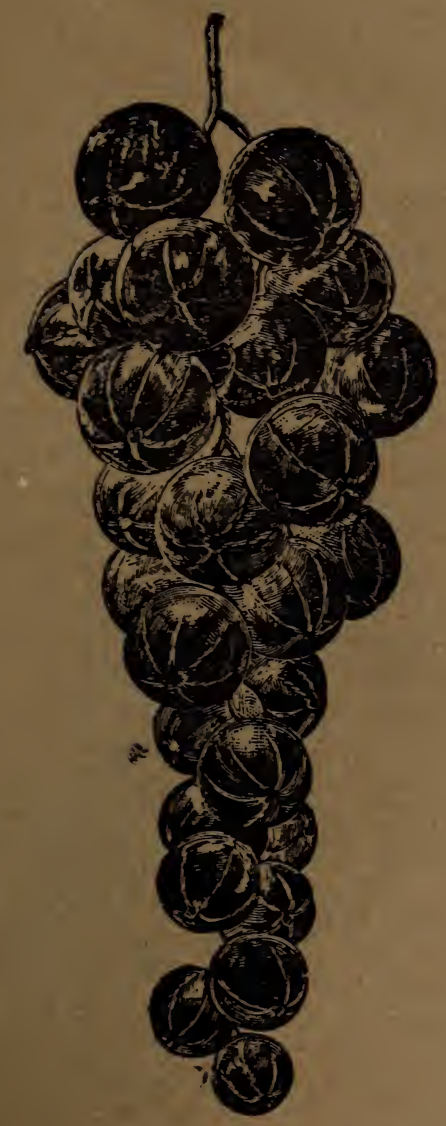

VICTORIA CURRANT. 


\section{Fruits of the \\ Arlington Nurseries and Fruit Farm}

drew first and second prizes at the Paris Exposition in 1900 , also at the different expositions held in the United States within the last few years.

$$
\begin{gathered}
20,000 \text { Quarts of Blackberries, } \\
\text { 5,000 Baskets of Grapes, } \\
\text { 3,000 Baskets of Cherries }
\end{gathered}
$$

Are not uncommon yields of the vineyards and small fruit plantations during a single season.

Also in connection with the business are orchards of-

4,000 Bearing Apple Trees.

1,700 Bearing Cherry Trees.

500 Bearing Plum Trees.

500 Bearing Peach Trees.

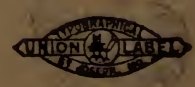

Press of The Western Fruit-Grower St. Joseph, Mo. 